\title{
Saponins from Quillaja saponaria and Quillaja brasiliensis: Particular Chemical Characteristics and Biological Activities
}

\author{
Juliane Deise Fleck ${ }^{1}$, Andresa Heemann Betti ${ }^{2}$, Francini Pereira da Silva ${ }^{1}$, \\ Eduardo Artur Troian ${ }^{1}$, Cristina Olivaro ${ }^{3}$, Fernando Ferreira 4 (D) and Simone Gasparin Verza ${ }^{1, *}$ \\ 1 Molecular Microbiology Laboratory, Institute of Health Sciences, Feevale University, \\ Novo Hamburgo 93525-075, RS, Brazil; julianefleck@feevale.br (J.D.F.); \\ pereiradasilvafrancini@gmail.com (F.P.d.S.); eatroia@gmail.com (E.A.T.) \\ 2 Bioanalysis Laboratory, Institute of Health Sciences, Feevale University, Novo Hamburgo 93525-075, RS, \\ Brazil; andresa@feevale.br \\ 3 Science and Chemical Technology Department, University Center of Tacuarembó, Udelar, Tacuarembó 45000, \\ Uruguay; cristina.olivaro@cut.edu.uy \\ 4 Organic Chemistry Department, Carbohydrates and Glycoconjugates Laboratory, Udelar, \\ Mondevideo 11600, Uruguay; ff@fq.edu.uy \\ * Correspondence: simonev@feevale.br; Tel.: +55-51-3586-8800
}

Academic Editors: Vassilios Roussis and Efstathia Ioannou

Received: 25 October 2018; Accepted: 28 December 2018; Published: 4 January 2019

\begin{abstract}
Quillaja saponaria Molina represents the main source of saponins for industrial applications. Q. saponaria triterpenoids have been studied for more than four decades and their relevance is due to their biological activities, especially as a vaccine adjuvant and immunostimulant, which have led to important research in the field of vaccine development. These saponins, alone or incorporated into immunostimulating complexes (ISCOMs), are able to modulate immunity by increasing antigen uptake, stimulating cytotoxic T lymphocyte production (Th1) and cytokines (Th2) in response to different antigens. Furthermore, antiviral, antifungal, antibacterial, antiparasitic, and antitumor activities are also reported as important biological properties of Quillaja triterpenoids. Recently, other saponins from Q. brasiliensis (A. St.-Hill. \& Tul.) Mart. were successfully tested and showed similar chemical and biological properties to those of $Q$. saponaria barks. The aim of this manuscript is to summarize the current advances in phytochemical and pharmacological knowledge of saponins from Quillaja plants, including the particular chemical characteristics of these triterpenoids. The potential applications of Quillaja saponins to stimulate further drug discovery research will be provided.
\end{abstract}

Keywords: triterpenoids; Quillaja saponaria; Quillaja brasiliensis; vaccine; immunoadjuvant; antimicrobial; antiviral

\section{Introduction}

Quillaja saponaria Molina is commonly found in Peru, Chile, and Bolivia. It was first described in 1782 due to the saponin content in the bark. The expression 'saponin' is Latin in origin: the word sapo that means 'soap', since saponins form foams when mixed with water [1,2]. The amphiphilic structure of saponins, due to their lipophilic aglycones and hydrophilic saccharide side chains, is responsible for the foam formation and chemical properties [1,2]. The most commonly reported aglycone from Q. saponaria, i.e., quilaic acid [3,4], is characterized by an aldehyde group at the C-23 position. The acyl side chain, another characteristic of Quillaja saponins, seems to also play an important role in some biological activities [5]. 
Saponins from Q. saponaria have a wide range of applications. Historically, Quillaja bark saponins have been used as a detergent. Nowadays they are approved for use as food additives in 187 signatory countries of the Codex Alimentarius, including the European Union, the United Kingdom, the United States, China, and Japan [6], the latter of which also allows its use in cosmetics [7]. The European Commission of Cosmetic Ingredients (CosIng) database has listed some Quillaja products as cosmetic ingredients, such as the bark, bark extract, root extract, and wood extract. Depending on the material used, different functions are attributed, such as antidandruff, cleansing, emulsifying, foaming, masking, moisturizing, skin conditioning, and surfactant [8].

Nowadays, there is increasing interest in using saponins as natural emulsifiers, alone or blended with others. Numerous studies have reported that Quillaja saponins are good emulsifiers for $\mathrm{O} / \mathrm{W}$ emulsions $[7,9,10]$ and nanoemulsions [10]. Recently, a food ingredient containing Quillaja bark saponins (Q-Naturale ${ }^{\circledR}$ ) was approved by the FDA as an effective emulsifier for beverages $[6,10]$.

In addition to their detergent and emulsifying properties, other pharmacological activities, including antiviral [11-13], antifungal [14], antibacterial [15-17], and antiparasitic ones, have been reported for Quillaja saponins. Regarding its biological properties, Q. saponaria has been included in the European and Brazilian Pharmacopoeias. The raw material is recommended as a cough reliever and expectorant, anti-inflammatory, hypocholesterolemic, and hemolytic agent. Topically, it has been indicated to treat scalp diseases (dandruff and hair loss) and other dermatological disorders. In the African Pharmacopoeia, Quillaja bark has been indicated as an emulsifying agent only.

Meanwhile, the strong immunoadjuvant activity reported for Quil- $\mathrm{A}^{\circledR}$, a crude extract of Q. saponaria bark, and its derivatives, makes them ideal substances for vaccine development [5,18-21]. Since Quil- $\mathrm{A}^{\circledR}$ is a heterogeneous mixture of saponins, its various components may exhibit different biological properties, including toxicological effects [5]. Thus, more purified saponin fractions have been obtained, especially QS-21, which has been applied in preclinical studies and clinical trials $[5,21]$.

An improvement to reduce saponin toxicity and enhance immunoadjuvant activity has been reported with the development of immunostimulating complexes (ISCOMs). ISCOMS are cage-like particles $(40 \mathrm{~nm})$, composed of saponins derived from Q. saponaria, phospholipids, cholesterol, and the targeted antigen [22-24]. Recently, a purified fraction of Quillaja brasiliensis saponins was also tested in ISCOMs, and the typical cage-like structures were viewed [25]. It is important to note that these structures are described only for Quillaja species.

Q. brasiliensis is native to Northern Uruguay, Southern Brazil, Northeastern Argentina, and Eastern Paraguay. It has also been studied as an immunoadjuvant, with crude extracts and purified saponin fractions being evaluated and shown to stimulate a great immune response to viral antigens, as observed with saponins from Q. saponaria [25-28]. Saponins are also abundant in the leaves of $Q$. brasiliensis, which represents a renewable source of these substances, since in $Q$. saponaria the main source of saponins is the barks of the tree. Nowadays, the overexploitation of native forests has been replaced and other alternative sources are available such as synthetic analogues of QS-21 saponin. Meanwhile, natural alternative sources of these products are also important [29].

Considering the relevance and biological properties already described for Quillaja species, a systematic review of published trials was accomplished with respect to their chemical characteristics and biological activities. To perform the review, the PubMed database was searched using the keywords Quillaja saponins, chemical characteristics, biological activity, adjuvant, antiviral, antifungal, antibacterial, and toxicity, either alone or in combination.

\section{Chemical Structure/Characterization}

Despite their widespread use, the structure of $Q$. saponaria saponins was not completely elucidated until 1986, when Higuchi et al. [3] published the structure of two deacetylated saponins from Q. saponaria bark (Figure 1, Figure 2 and Table 1). Further isolation and structural studies allowed for the identification of nearly 60 saponins from $Q$. saponaria, sharing several structural motifs. These saponins contain a triterpenic aglycone belonging to the $\beta$-amyrin series, most frequently quillaic acid (Figure 1 ). 


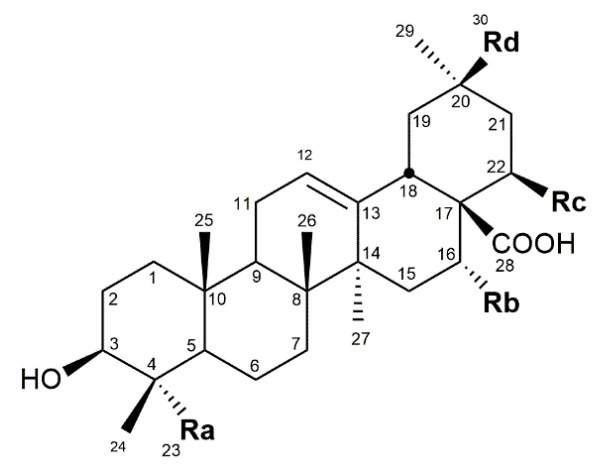

$\begin{array}{lcllll}\text { Triterpene } & \text { Abbreviations } & \text { Ra } & \text { Rb } & \text { Rc } & \text { Rd } \\ \text { Quillaic acid } & & & & & \\ \text { Quillaic acid, 22 } \beta-O H & \text { Q-OH } & \mathrm{CHO} & \mathrm{OH} & \mathrm{H} & \mathrm{CH}_{3} \\ \text { Gypsogenin } & \mathrm{G} & \mathrm{CHO} & \mathrm{OH} & \mathrm{OH} & \mathrm{CH}_{3} \\ \text { Phytolaccinic acid } & \mathrm{P} & \mathrm{H} & \mathrm{H} & \mathrm{CH}_{3} \\ \text { Phytolaccinic acid, 23-O-Ac } & \text { P-Ac } & \mathrm{CH}_{2} \mathrm{OH} & \mathrm{H} & \mathrm{H} & \mathrm{COOCH}_{3} \\ \text { Echynocystic acid } & \text { E } & \mathrm{CH}_{3} & \mathrm{H} & \mathrm{H} & \mathrm{COOCH}_{3} \\ & & & \mathrm{OH} & \mathrm{H} & \mathrm{CH}_{3}\end{array}$

Figure 1. Reported triterpene aglycones in Quillaja saponaria and/or Q. brasiliensis saponins.
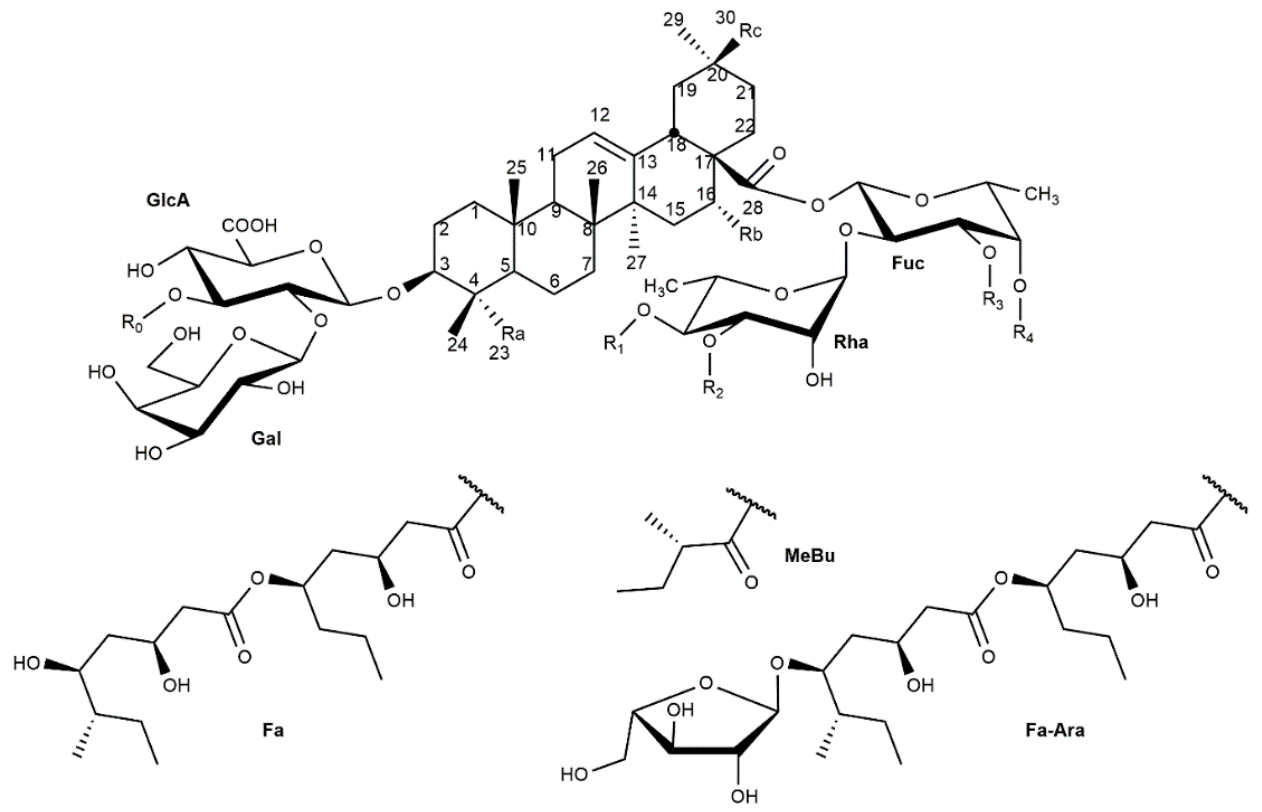

Figure 2. General structure of $Q$. saponaria and Q. brasiliensis saponins.

These saponins are bidesmosides, glycosylated at the C-3 and C-28 positions of the aglycone (Figure 2). The C-3 position of the aglycone is most frequently glycosylated by the disaccharide residue $\beta$-D-Gal $p-(1 \rightarrow 2)-\beta$-D-GlcA $p$, most frequently branched at the O-3 position of the glucuronic acid unit with a $\alpha$-L-Rhap or a $\beta$-D-Xyl $p$ residue. In a few cases, the saponin lacks the C-28 linked oligosaccharide (saponins 3-5, Table 1), but normally this position is glycosylated through an acetal-ester linkage to a complex oligosaccharide. This oligosaccharide has a conserved moiety composed of the disaccharide $\alpha$-L-Rhap-( $1 \rightarrow 2)-\beta$-D-Fuc $p$ with different decorations [30]. More often this disaccharide is extended by a $\beta$-D-Xyl- $(1 \rightarrow 4)$ residue, which can bear a second $\beta$-D-Xyl $p(1 \rightarrow 3)$ residue or a $\beta$-D-Apif $(1 \rightarrow 3)$ residue. The $\beta$-D-Fuc $p$ residue of the constant disaccharide can present either a $\alpha$-L-Rhap or a $\beta$-D-Glc $p$ at O-3, and can be acetylated or not. The $\beta$-D-Fuc $p$ residue can be acylated at O-4, simply with an acetate residue or a branched ester dimer composed of two units of 3,5-dihidroxy-octanoic acid, called Fa, 
which can be glycosylated in the terminal 5-hidroxy group by a $\beta$-D-Araf residue (Figure 2) [30]. This terminal $\beta$-D-Ara $f$ residue can also bear a $(1 \rightarrow 2)-\beta$-D-Glc $p$ residue.

The $\beta$-D-Fuc $p$ residue linked to C-28 can be acylated at O-4 (R4 in Figure 1, see Table 1). However, the corresponding regioisomers acylated at the O-3 position can be found in solution due to a transesterification reaction between these two cis-vicinal hydroxyl groups, as has been observed in the adjuvant saponin QS-21. The rate of this isomerization is higher at $\mathrm{pH}>5.5$, leading to an equilibrium mixture of both isomers [31].

Phytochemical studies of the less known Quillaja brasiliensis tree, even though it is a well-known rich source of saponins, started relatively later. In a pioneering study, a prosapogenin composed of quillaic acid glycosylated at C-3 with a $\beta$-D-GlcA $p$ residue was isolated from the products of partial hydrolysis, suggesting that these saponins might also present structures like those from Q. saponaria [32]. Recently, Wallace et al. [29] presented the first structural studies of complete Q. brasiliensis saponins using electrospray ionization ion trap-multiple stage mass spectrometry (ESI-IT-MSn). These authors identified 27 bidesmosidic triterpenic saponins, with either quillaic acid, gypsogenin, phytolaccinic acid, or 23-O-acetyl-phytolaccinic acid as aglycones (Figure 1). The Q. brasiliensis saponins described present glycosylation patterns at positions C-3 and C-28 of the aglycone analogous to those of Q. saponaria saponins with the same conserved motifs (Figure 2). Some saponins presented different degrees of acylation, and regioisomers with the Fa acyl substituent at the O-4 or the O-3 positions of the $\beta$-D-Fucp residue were found, as well as the presence of the QS-21 Xyl and QS-21 Api saponins (S4/S6, Table 1).

Table 1. Structures of Quillaja saponaria saponins.

\begin{tabular}{|c|c|c|c|c|c|c|c|c|c|}
\hline \multirow{2}{*}{$\mathbf{N}^{o}$} & \multirow{2}{*}{ Saponin } & \multirow{2}{*}{ Mi } & \multicolumn{6}{|c|}{ Structure } & \multirow{2}{*}{ Ref. } \\
\hline & & & Aglycone & R0 & R1 & $\mathbf{R} 2$ & R3 & R4 & \\
\hline 1 & DS-1 & 1512.0 & $Q$ & Xyl & Api-Xyl & $\mathrm{H}$ & $\mathrm{H}$ & & [3] \\
\hline 2 & DS-2 & 1674.0 & $\widehat{Q}$ & Xyl & Api-Xyl & $\mathrm{H}$ & Glc & & [3] \\
\hline 3 & $*$ & 824.0 & $\mathrm{Q}$ & $\mathrm{H}$ & - & - & - & - & [33] \\
\hline 4 & * & 970.0 & $\widehat{Q}$ & Rha & - & - & - & - & [33] \\
\hline 5 & * & 956.0 & $\hat{\mathrm{Q}}$ & Xyl & - & - & - & - & [34] \\
\hline 6 & 4 & 1436.6 & $\widehat{Q}$ & $\mathrm{H}$ & Xyl & $\mathrm{H}$ & Rha & Ac & [34] \\
\hline 7 & 5 & 1582.7 & $\widehat{Q}$ & Rha & Xyl & $\mathrm{H}$ & Rha & Ac & [34] \\
\hline 8 & 6 & 1568.7 & $\bar{Q}$ & Xyl & Xyl & $\mathrm{H}$ & Rha & Ac & [34] \\
\hline 9 & 7 & 1714.7 & $\widehat{Q}$ & Rha & Xyl-Api & $\mathrm{H}$ & Rha & Ac & [34] \\
\hline 10 & 8 & 1700.7 & $\widehat{Q}$ & Xyl & Xyl-Api & $\mathrm{H}$ & Rha & Ac & [34] \\
\hline 11 & 9 & 1714.7 & $\widehat{Q}$ & Rha & Xyl-Xyl & $\mathrm{H}$ & Rha & Ac & [34] \\
\hline 12 & 10 & 1700.7 & $\mathrm{Q}$ & Xyl & Xyl-Xyl & $\mathrm{H}$ & Rha & Ac & [34] \\
\hline 13 & $11 a$ & 1598.7 & $\hat{\mathrm{Q}}$ & Rha & Xyl & $\mathrm{H}$ & Glc & Ac & [35] \\
\hline 14 & $11 \mathrm{~b}$ & 1584.7 & $\mathrm{Q}$ & Xyl & Xyl & $\mathrm{H}$ & Glc & Ac & [35] \\
\hline 15 & $12 a$ & 1628.7 & $\hat{\mathrm{Q}}$ & Rha & $\mathrm{H}$ & Glc & Glc & Ac & [35] \\
\hline 16 & $12 b$ & 1614.7 & $\hat{\mathrm{Q}}$ & Xyl & $\mathrm{H}$ & Glc & Glc & $\mathrm{Ac}$ & [35] \\
\hline 17 & $13 a$ & 1730.7 & $\widehat{Q}$ & Rha & Xyl-Api & Glc & $\mathrm{H}$ & Ac & [35] \\
\hline 18 & $13 b$ & 1716.7 & $\mathrm{Q}$ & Xyl & Xyl-Api & Glc & $\mathrm{H}$ & Ac & [35] \\
\hline 19 & $14 a$ & 1760.8 & $\hat{\mathrm{Q}}$ & Rha & Xyl & Glc & Glc & Ac & [35] \\
\hline 20 & $14 \mathrm{~b}$ & 1746.7 & $\mathrm{Q}$ & Xyl & Xyl & Glc & Glc & Ac & [35] \\
\hline 21 & $15 a$ & 1640.7 & $\widehat{Q}$ & Rha & Xyl & $\mathrm{H}$ & Glc-Ac & Ac & [35] \\
\hline 22 & $15 b$ & 1626.7 & $\widehat{Q}$ & Xyl & Xyl & $\mathrm{H}$ & Glc-Ac & Ac & [35] \\
\hline 23 & $16 a$ & 1802.8 & $\mathrm{Q}$ & Rha & Xyl & Glc & Glc-Ac & Ac & [35] \\
\hline 24 & $16 \mathrm{~b}$ & 1788.7 & $\mathrm{Q}$ & Xyl & Xyl & Glc & Glc-Ac & Ac & [35] \\
\hline 25 & $17 a$ & 1744.8 & $\bar{Q}$ & Rha & Xyl & Glc & Rha & Ac & [35] \\
\hline 26 & $17 \mathrm{~b}$ & 1730.7 & $\widehat{Q}$ & Xyl & Xyl & Glc & Rha & Ac & [35] \\
\hline
\end{tabular}


Table 1. Cont.

\begin{tabular}{|c|c|c|c|c|c|c|c|c|c|}
\hline \multirow{2}{*}{$\mathbf{N}^{\circ}$} & \multirow{2}{*}{ Saponin } & \multirow{2}{*}{ Mi } & \multicolumn{6}{|c|}{ Structure } & \multirow{2}{*}{ Ref. } \\
\hline & & & Aglycone & R0 & R1 & R2 & R3 & R4 & \\
\hline 27 & $18 \mathrm{a}$ & 1876.8 & $\mathrm{Q}$ & Rha & Xyl-Api & Glc & Rha & Ac & [35] \\
\hline 28 & $18 \mathrm{~b}$ & 1862.8 & $\widehat{Q}$ & Xyl & Xyl-Api & Glc & Rha & Ac & [35] \\
\hline 29 & $\mathrm{~S} 1$ & 1870.9 & $\bar{Q}$ & Rha & Xyl & $\mathrm{H}$ & $\mathrm{H}$ & Fa-Ara & [36] \\
\hline 30 & S2 & 1856.9 & $\hat{\mathrm{Q}}$ & Xyl & Xyl & $\mathrm{H}$ & $\mathrm{H}$ & Fa-Ara & [36] \\
\hline 31 & S3 & 2002.9 & $\mathrm{Q}$ & Rha & Xyl-Xyl & $\mathrm{H}$ & $\mathrm{H}$ & Fa-Ara & [36] \\
\hline 32 & S4 & 1988.9 & $\widetilde{Q}$ & Xyl & Xyl-Xyl & $\mathrm{H}$ & $\mathrm{H}$ & Fa-Ara & [36] \\
\hline 33 & S5 & 2002.9 & $\mathrm{Q}$ & Rha & Xyl-Api & $\mathrm{H}$ & $\mathrm{H}$ & Fa-Ara & [36] \\
\hline 34 & S6 & 1988.9 & $\hat{\mathrm{Q}}$ & Xyl & Xyl-Api & $\mathrm{H}$ & $\mathrm{H}$ & Fa-Ara & [36] \\
\hline 35 & S7 & 1912.9 & $\mathrm{Q}$ & Rha & Xyl & $\mathrm{H}$ & Ac & Fa-Ara & {$[4]$} \\
\hline 36 & S8 & 1898.9 & $\mathrm{Q}$ & Xyl & Xyl & $\mathrm{H}$ & Ac & Fa-Ara & [4] \\
\hline 37 & S9 & 2045.0 & $\mathrm{Q}$ & Rha & Xyl-Xyl & $\mathrm{H}$ & Ac & Fa-Ara & [4] \\
\hline 38 & S10 & 2030.9 & $\widehat{Q}$ & Xyl & Xyl-Xyl & $\mathrm{H}$ & Ac & Fa-Ara & {$[4]$} \\
\hline 39 & S11 & 2045.0 & $\mathrm{Q}$ & Rha & Xyl-Api & $\mathrm{H}$ & Ac & Fa-Ara & {$[4]$} \\
\hline 40 & S12 & 2030.9 & $\hat{\mathrm{Q}}$ & Xyl & Xyl-Api & $\mathrm{H}$ & Ac & Fa-Ara & [4] \\
\hline 41 & B1 & 2033.0 & $\mathrm{Q}$ & Rha & Xyl & Glc & $\mathrm{H}$ & Fa-Ara & [36] \\
\hline 42 & B2 & 2018.9 & $\widehat{Q}$ & Xyl & Xyl & Glc & $\mathrm{H}$ & Fa-Ara & [36] \\
\hline 43 & B3 & 2165.0 & $\hat{\mathrm{Q}}$ & Rha & Xyl-Api & Glc & $\mathrm{H}$ & Fa-Ara & [36] \\
\hline 44 & B4 & 2151.0 & $\widehat{Q}$ & Xyl & Xyl-Api & Glc & $\mathrm{H}$ & Fa-Ara & [36] \\
\hline 45 & B5 & 2165.0 & $\widehat{\mathrm{Q}}$ & Rha & Xyl-Xyl & Glc & $\mathrm{H}$ & Fa-Ara & [37] \\
\hline 46 & B6 & 2151.0 & $\hat{\mathrm{Q}}$ & Xyl & Xyl-Xyl & Glc & $\mathrm{H}$ & Fa-Ara & [37] \\
\hline 47 & B7 & 1886.9 & $\widehat{Q}$ & $\mathrm{H}$ & Xyl & Glc & $\mathrm{H}$ & Fa-Ara & [37] \\
\hline 48 & B8 & 2018.9 & Q & $\mathrm{H}$ & Xyl-Api & Glc & $\mathrm{H}$ & Fa-Ara & [37] \\
\hline 49 & QS-III & 2297.0 & $\widehat{Q}$ & Xyl & Xyl-Api & Glc & Fa-Ara-Rha & $\mathrm{H}$ & [3] \\
\hline 50 & $20 a$ & 1656.7 & $\mathrm{Q}-\mathrm{OH}$ & Rha & Xyl & Glc & $\mathrm{H}$ & $\mathrm{MeBu}$ & [34] \\
\hline 51 & $20 \mathrm{~b}$ & 1642.7 & $\widehat{\mathrm{Q}}-\mathrm{OH}$ & Xyl & Xyl & Glc & $\mathrm{H}$ & $\mathrm{MeBu}$ & [34] \\
\hline 52 & $21 a$ & 1788.8 & $\mathrm{Q}-\mathrm{OH}$ & Rha & Xyl-Api & Glc & $\mathrm{H}$ & $\mathrm{MeBu}$ & [34] \\
\hline 53 & $21 b$ & 1774.8 & $\widehat{\mathrm{Q}}-\mathrm{OH}$ & Xyl & Xyl-Api & Glc & $\mathrm{H}$ & $\mathrm{MeBu}$ & [34] \\
\hline 54 & $22 a$ & 1978.9 & $\mathrm{Q}-\mathrm{OH}$ & Rha & Xyl-Api & Glc & Rha & OHMeHex & [34] \\
\hline 55 & $22 b$ & 1964.9 & $\widehat{\mathrm{Q}}-\mathrm{OH}$ & Xyl & Xyl-Api & Glc & Rha & OHMeHex & [34] \\
\hline 56 & 19 & 1392.7 & $\mathrm{P}$ & $\mathrm{H}$ & $\mathrm{H}$ & $\mathrm{H}$ & Glc & $\mathrm{MeBu}$ & [34] \\
\hline 57 & 23 & 1732.8 & $\mathrm{E}$ & Xyl & Xyl & Glc & Glc & Ac & [34] \\
\hline 58 & S13 & 1560.7 & P-Ac & $\mathrm{H}$ & $\mathrm{H}$ & $\mathrm{MeBu}$ & Glc & $\mathrm{MeBu}$ & {$[4]$} \\
\hline
\end{tabular}

*: Monodesmosidic C-3 saponins. DS: deacylateded saponins, Q: quillaic acid, Q-OH: quillaic acid, 22 $\beta-\mathrm{OH}, \mathrm{P}$ : phytolaccinic acid, P-Ac: phytolaccinic acid, 23-O-Ac, E: echynocystic acid. Fa-Ara: see Figure 2, QS_III: quillaja saponin with highest molecular mass, MeBu: 2-methylbutanoyl, OHMeHex: 3-hydroxy-4-methylhexanoyl. Adapted from Kite et al. [30].

\section{Biological Activities}

Regarding the biological activities, Quillaja saponins have been widely studied. The main activities described are reviewed below, especially the antibacterial, antiviral, antifungal, antiparasitic, antitumor, hepatoprotective, and immunoadjuvant ones.

\subsection{Antimicrobial Activities of Quillaja Saponins}

The antimicrobial activities of saponins from Quillaja are described in several studies, especially their antibacterial, antifungal, and antiviral ones [11,12,14,15,38-40]. The main reason for these activities is the affinity of the aglycone with cell membrane cholesterol, leading to changes in the membrane and, consequently, preventing microorganism infection of the cell [41,42].

\subsubsection{Antibacterial Activity}

Saponins present detergent properties by destroying membrane lipids and, for this reason, they can make the bacterial cell membranes permeable facilitating the influx of molecules through the bacterial wall, such as antibiotics [43-45]. On the other hand, a study conducted with clinical 
strains of multiresistant Escherichia coli isolated from human urine demonstrated that commercial saponin from $Q$. saponaria barks $(12 \mu \mathrm{g} / \mathrm{mL})$ significantly increased the growth of the six strains tested. In susceptibility tests of $E$. coli strains against ampicillin, streptomycin, and ciprofloxacin, saponins increased the colony forming units per $\mathrm{mL}(\mathrm{CFU} / \mathrm{mL})$, even in the presence of antibiotics [46].

Saponin extracts from $Q$. saponaria are sold in the market and produced by different brands, and their composition can vary according to the process used to obtain them. Therefore, the antimicrobial activity may be altered since the constitution and nature of the saponins differs. Sen et al. [16] evaluated the anti E. coli action of Q. saponaria saponins from three different commercial companies (Carl Roth $\mathrm{GmbH}^{\circledR}$, Karlsruhe, Germany; Sigma ${ }^{\circledR}$, Saint Louis, MO, USA; Quillaja 300 Powder $^{\circledR}$, Nor-feed, Hvidovre, Denmark). The study showed different results between the three brands used, in which the CFU increased with the different concentrations of saponins used. The percentage of bacterial growth was $151 \%, 31 \%$, and $97 \%$ for the Roth, Sigma, and Nor-feed brands, respectively. The activity of $Q$. saponaria saponins, in the induction of bacterial growth, indicates that they may act by facilitating the transport of nutrients from the bacterial growth media into the microorganism by increasing bacterial permeability though the cell membranes, thus stimulating the colonies' growth $[16,46]$.

In contrast, Hassan et al. [38] showed the antibacterial activity of a commercial extract rich in Quillaja saponins (Sigma ${ }^{\circledR}$ ) against Salmonella typhimurium, Staphylococcus aureus, and E. coli. Similarly, Sewlikar and D'Souza [47] observed the strong antibacterial activity of the aqueous extract of Q. saponaria against four strains of E. coli producers of Shiga toxin (STEC) O157:H7 and six non-O157 STEC serotypes. At the time of treatment with the extracts, the 4 O157:H7 strains had an initial CFU of approximately $7.5 \mathrm{log}$ and after $16 \mathrm{~h}$ of treatment, the remaining counts were reduced to 6.79 and $3.5 \log$ CFU at room temperature. The non-O157 STECs treated with Q. saponaria showed reductions of 6.81 to $4.55 \log$ CFU after $16 \mathrm{~h}$ at room temperature. Additional tests showed that incubation at $37^{\circ} \mathrm{C}$ reduced the CFU to undetectable levels (control without any significant reduction) after $1 \mathrm{~h}$ of treatment for all O157:H7 strains and 30 min post-treatment for non-O157. Scanning electron microscopy analysis revealed the damage to bacteria cell membranes subjected to the treatment.

The commercial extract of $Q$. saponaria saponins $\left(\right.$ Sigma $\left.{ }^{\circledR}\right)$ was shown to be a relevant agent for increasing the efficiency of the disinfection process of the bacteria genus Asaia. Pretreatment with $1 \%$ saponin solution resulted in increased sensitivity of the bacterial cultures tested. Cultures pre-exposed to saponin solution and submitted to $N$-ethyl- $N, N$-dimethylhexadecylammonium bromide (QAC) showed half of the minimum inhibitory concentration (MIC) compared to non-saponin-treated bacteria. In tests performed with peracetic acid, the difference in MICs was 4 to 8-times lower than the bacterial strains without saponin pre-treatment. With these findings, the authors suggest that treatment with saponin solution prior to disinfection may reduce the need for high concentrations of the antimicrobials tested. Concerning the inhibition of bacterial biofilms, experiments conducted in this same study revealed that the extract reduced the live cells number in biofilms by approximately 4 to $5 \log$ [48]. Different studies on the antibacterial activity of $Q$. saponaria saponins suggest that saponins' biological activity is related to their chemical constitution, thus different microorganisms have different susceptibilities to saponin action $[49,50]$.

\subsubsection{Antiviral Activity}

Two extracts of $Q$. saponaria, Ultra Dry $100 \mathrm{Q}$ (a spray-dried purified aqueous extract, consisting of $65 \%$ saponins) and Vax sap (purified medical grade material, obtained by an additional purification of Ultra Dry 100 Q, with saponin content greater than 90\%), showed antiviral activity in vitro and in vivo. Ultra Dry 100 Q showed strong antiviral action against herpes simplex virus type 1, vaccinia virus, human immunodeficiency viruses 1 and 2, varicella zoster virus, rhesus rotavirus (RRV), and reovirus. Very low concentrations of the extract were able to prevent the virus from infecting their host cells and were still able to maintain their blocking activity and stop the virus binding to the cells for up to $16 \mathrm{~h}$ after their removal from the culture medium. Both extracts studied prevented the binding of RRV and reovirus to host cells pretreated with them, also inhibiting the propagation of infectious 
particles to the uninfected neighboring cells. This cell protecting effect persisted for up to $16 \mathrm{~h}$ after the extracts were removed from the cell monolayers $[11,13]$. The action of saponins is possibly due to the cell membrane and the affinity of the aglycone portion with the membrane cholesterol. Consequently, without the cholesterol, the fluidity of the cell membrane increases, causing it to be beyond the control of the enzymatic activities. Thus, saponins may act in cellular proteins by preventing specific binding of viral receptors $[41,51]$.

Confirming the evidence shown in the in vitro tests, in which the saponin-rich extracts of Q. saponaria Molina are able to inhibit RRV infection in host cells by some modification in the cell membrane proteins preventing binding of viral receptors, in vivo experiments with Vax sap extract presented strong anti-RRV action. Newborn mice were exposed to the aqueous extract for two days and, afterwards, RRV was administered for another five consecutive days. Doses of $0.015 \mathrm{mg} / \mathrm{mouse}$ reduced the diarrhea caused by the virus by $68 \%$ in mice exposed to 500 plaque forming units (PFU). The experiments revealed that lower concentrations of the extract do not have a strong antiviral effect when administered in higher viral titers (5000 PFU). In addition, in the case of a higher inoculant (50,000 PFU), an extract concentration of $0.03 \mathrm{mg} /$ mouse blocked virus infection, also reducing diarrhea in the animals [12].

\subsubsection{Antifungal Activity}

Membranes of regenerated cellulose nanofibers supplemented with Q. saponaria saponins are described as having antifungal activity. Dixit et al. [14] verified that, after $24 \mathrm{~h}$, the nanofiber membranes containing dead spores of Penicillium roguefortii Thom caused an $80.4 \%$ grown reduction and Aspergillus ochraceus anamorph resulted in a 53.6\% reduction. In addition, Chapagain et al. [52] described moderate activity of $Q$. saponaria bark saponins against different fungal species: Alternaria solani (47.5\%), Pythium ultimum (59.12\%), Fusarium oxysporum (56.11\%), and Verticillium dahliae (35.92\%), but not for Colletotrichum coccodes species.

\subsection{Antiparasitic Activity}

The saponins from $Q$. saponaria barks showed antiparasitic activity, in vitro, in a ruminal fermentation system $[15,39,40]$. A commercial extract of $Q$. saponaria revealed an antiparasitic effect inversely proportional to the extract concentrations tested [17].

Quillaja saponins were also evaluated against cloned xenic cultures of different isolates of Blastocystis sp., Tetratrichomonas gallinarum, and Histomonas meleagridis. The in vitro assays for antiprotozoal activity showed that the effect of this plant's saponins are directed towards the protozoa, although more studies are necessary to elucidate the mode of action of saponins though the parasites [53].

A study performed to evaluate the effect of commercial saponins obtained from $Q$. saponaria reduced the viability of the protozoan Trichomonas vaginalis by $100 \%$ at a $0.025 \%$ concentration of the extract in culture medium. The aqueous extract of $Q$. brasiliensis leaves also showed anti-T. vaginalis activity ( $0.1 \%$ inhibited $98 \%$ of the microorganism's growth). Further experiments demonstrated that saponins induced damage to the parasite membrane, suggesting that the extracts acted by inhibiting the viability of T. vaginalis [54]. This antiparasitic effect may be due to the detergent action of the saponins from the genus Quillaja in the cholesterol of the protozoa membranes, resulting in cell lysis. However, the activity may not occur in all protozoa species, since some species may not be susceptible to the toxic effects of saponins or the parasite may adapt to saponin effects $[42,50,55]$.

\subsection{Antitumor Activity of Quillaja Saponins}

Fractions rich in Quillaja saponins are also described as therapeutic agents for treating and preventing cancerous diseases [56]. One of the first studies to demonstrate the saponins' antitumor potential was conducted with Quil- ${ }^{\circledR}$, where the fraction prolonged the survival of mice with leukemia [57]. Since saponins interact with the cholesterol of cell membranes and, consequently, 
cause membrane damage, cell lysis, and necrosis, they present high toxicity for clinical practice. These toxic effects have been reversed by converting $Q$. saponaria fractions into stable nanoparticles, binding them to cholesterol. The QS fraction 21 (QS-21) (a more hydrophobic fraction with an acyl chain-ASAP) formulated in killing and growth inhibiting (KGI) particles selectively killed nine of the ten tumor cell lines at a concentration 30 times lower than the concentration required to kill normal monocytes. In addition, the ASAP's lytic effect on red blood cells was inhibited by the formulation with KGI particles; cell death occurred through the apoptosis mechanism [58].

\subsection{Hepatoprotective Activity of Quillaja Saponins}

Thought-provokingly, Abdel-Reheim et al. [59] demonstrated that bark saponins from Q. saponaria are interesting hepatoprotective agents. In this study, the authors verified that saponin significantly decreased the elevation of ALT (achieving 57\% hepatotoxicity control), AST (66\%), ALP (76\%), GGT (60\%), NOx (77\%), TC (70\%), MDA (65\%), LDH (54\%), TG (54\%), and total (54\%), direct (54\%), and indirect (54\%) bilirubin, coupled with increased GSH (219\%) and albumin (159\%) levels. Furthermore, saponin from Quillaja bark significantly decreased liver MDA and NOx production, reinforcing that saponin has antioxidant properties, since it is able to scavenge excessive radicals and thus suppress oxidative stress $[60,61]$. The hepatoprotective effect of Quillaja bark saponin is probably due to the amelioration of oxidative stress and suppression of NOS expression, maintaining hepatocyte integrity and functioning. The decrease in TG and TC serum levels can be explained by the decrease in intestinal cholesterol absorption and by the reduction in cholesterol levels, accompanied by an increase in the HMG-CoA reductase activity and LDL receptor levels in the liver [62]. In addition, the immunohistochemical results help to explain Quillaja bark saponins' protective activity, since saponins suppressed NOS expression, attenuating oxidative and nitrosative stress [59].

\subsection{Immunoadjuvant Activity of Quillaja Saponins}

One remarkable biological activity is their ability to modulate immunity towards a more cell mediated response or to enhance antibody production $[18,21,63]$. This property is mainly correlated with vaccinology, since saponins can act as immunoadjuvants. Despite both steroid and triterpenoid saponins from different plant species demonstrating immunogenic activity, Quillaja triterpenoid saponins are the most extensively studied [18]. Because of their amphiphilic structure, both aglycone and branched sugar radicals play important roles in stimulating the immune system. In contrast to other saponin structures, Quillaja saponins feature a fatty acid chained to $\beta$-D-Fucp residue (C-28) and, at position 4, an aldehyde group, which increases their immunogenic activity leading to a more intense stimulation of the cytotoxic T lymphocytes (CTL) [20,64]. Although the immunogenic mechanism is not yet clearly understood, it is known that they can activate different pathways, including Nod-like Receptors (NLR) and Toll-like Receptors (TLR) [18,20].

Saponins can stimulate antigen-presenting cells (APC) by inducing inflammasome formation [21,65]. The inflammasome is a set of receptors and sensors that induce inflammation by activating caspase- 1 . Saponins can stimulate the secretion of IL- 6 and IL- $1 \beta$ in vitro despite requiring the activation of TLR4, leading to active forms of caspase-1. Also, saponins can stimulate the expression of TLR2 interferon- $\alpha$ leading to active forms of IL-18 and IL-1 $\beta$ [66,67]. Taken together, Marty-Roix et al. (2016) found that saponins can cause an enlargement of the lymph node, indicating cell recruitment or cell proliferation through cytokine signaling [68]. The fatty acid in their structure boosts the cytotoxicity of the CD8 lymphocyte by increasing the interaction of the saponins with the cell membrane through cholesterol, inducing the formation of cell pores and, possibly, signaling to CTLs [18-20,69].

As for the humoral response, saponins can suppress secretion of IL-4, thus lowering IgE levels. On the other hand, they can shift a Th2 response to a Th1 response, inducing the secretion of IgG2a rather than IgG1, indicating a more pronounced Th1 response than Th2 response through changes in cytokine secretion (in this context IL-2 and IFN $\gamma$ ) [20,70-72]. This mechanism may occur in 
two different ways: first, through the deacylated aldehyde that binds to $\mathrm{T}$ cell surface receptors (mostly CD2), leading the cell to Th1 immunity; and second, through endocytosis of the saponin with an antigen, disrupting the endosomal membrane of the processed antigen and facilitating the antigen presentation process (Figure 3) [20,69,73].

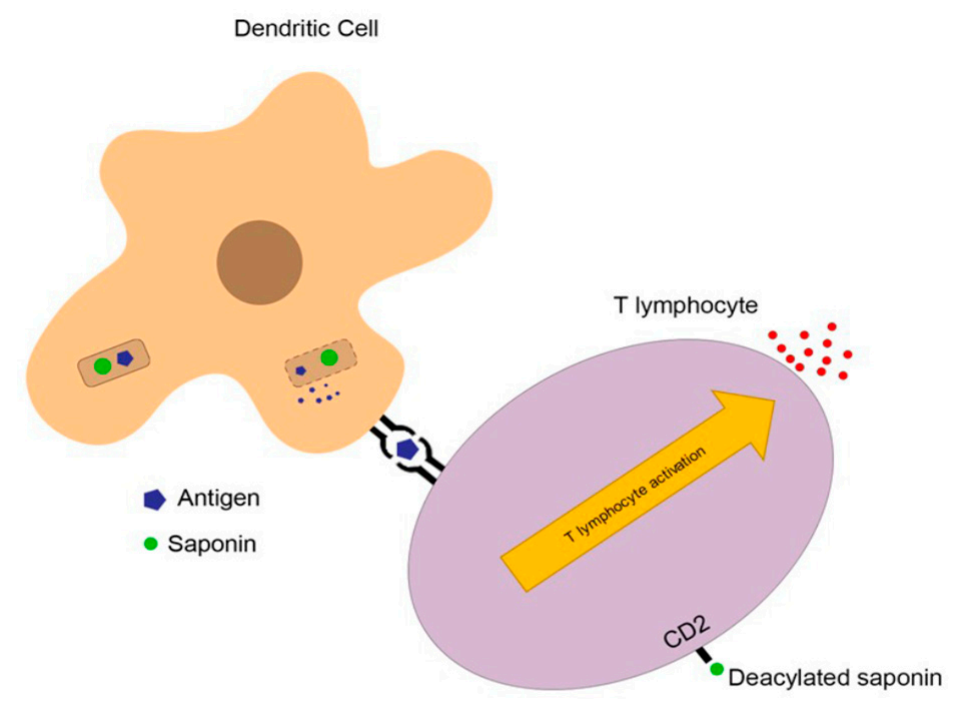

Figure 3. The endocytosis of the saponin with an antigen can cause disruption to the endosomal membrane of the processed antigen, facilitating the antigen presentation process by extravasation of the antigen and its transportation to the endoplasmic reticulum with posterior complexation with MHCI. Also, deacylated saponins can interact with naïve CD4 T-cells through CD2 receptors, stimulating T cell activation biased towards a Th1 response with consequent secretion of IL-2 and IFN $\gamma$.

Despite the immunogenic activity, the considerable toxicity restricts its use in humans. An alternative for reducing saponin toxicity and increasing its immunoadjuvancy is to formulate it with cholesterol and phospholipids into cage-like structures called Immune Stimulating Complexes (ISCOMs) [74]. These structures were first described in 1971 and shown to enhance antibody production when compared to saponins, mostly because they can be easily transported to lymph nodes due to their nanoscale size (up to 80 nanometers) [75-77]. ISCOMs can modulate immune response in different ways according to the antigen. It is known that some antigens can increase or decrease the production of IL-10, pushing the immune response towards a Th2 or Th1 response, respectively [78,79]. ISCOMs can also stimulate CTLs through cytokine modulation [77]. The immunogenic mechanism is not clearly understood, but it is probably related to saponins, since they cause similar changes in cytokine expression, leading to different T lymphocyte activation [77,78].

In vaccine systems, saponins can be used alone or complexed with different molecules (i.e., in oil/water, in different structures (liposomes) [80], or in ISCOMs [81,82]). Also, semisynthetic saponins can be used as adjuvants in order to reduce toxicity and maintain their immunoadjuvant properties [83]. Considering their effects when used as adjuvants in vaccines, they are promising candidates and have featured in plenty of pre-clinical studies for vaccines, as mentioned in Table 2. The studies reported in Table 2 are arranged by year of publication. 
Table 2. Pre-clinical studies using Quillaja saponins as an adjuvant in vaccine formulations targeting different antigens.

\begin{tabular}{|c|c|c|c|c|}
\hline Antigen & Adjuvant & Model & Findings & Ref \\
\hline $\begin{array}{l}\text { PorA P1.6 (membrane } \\
\text { porin of Neisseria } \\
\text { meningitidis) }\end{array}$ & Quil-A $^{\circledR}$ & Mice & $\begin{array}{l}\text { PorA supplemented with Quil-A }{ }^{\circledR} \text { resulted in four to seven times } \\
\text { higher antibody titers (IgG1, IgG2a, and IgG2b) when compared with } \\
\text { lipopolysaccharide as an adjuvant. }\end{array}$ & {$[84]$} \\
\hline $\begin{array}{l}\text { S. bovis and Lactobacillus } \\
\text { spp. }\end{array}$ & Quil-A $^{\circledR}$ & Cattle & $\begin{array}{l}\text { Immunization of feedlot steers against } S \text { bovis and Lactobacillus spp } \\
\text { with vaccines incorporating Freund adjuvant, Quil- } \mathrm{A}^{\circledR} \text {, dextran, or } \\
\text { alum as an adjuvant effectively induced high IgG concentrations } \\
\text { when dextran was used as an adjuvant. }\end{array}$ & {$[85]$} \\
\hline $\begin{array}{l}\text { 38-kDa mycobacterial } \\
\text { protein }\end{array}$ & ISCOMs & Mice & $\begin{array}{c}\text { An increase in antibody titers was observed after a booster injection, } \\
\text { with significant levels of IgG2a. The ISCOM formulations induced } \\
\text { this in the same way. Regarding the induction of CTL responses, the } \\
\text { differences shown comparing various ISCOMS formulations were } \\
\text { minimal. }\end{array}$ & {$[86]$} \\
\hline Tetanus toxoid & QS-21 & Mice & $\begin{array}{l}\text { Administration of QS-21 p.o. as an adjuvant elicits strong serum IgM } \\
\text { and IgG Ab responses. }\end{array}$ & {$[87]$} \\
\hline Babesian equi immunogen & Quil-A $^{\circledR}$ & Donkeys & $\begin{array}{l}\text { A mixture of Quil } \mathrm{A}^{\circledR} \text { and Babesia equi immunogen was optimal in } \\
\text { generating a significant immune response and reducing the lethality. }\end{array}$ & {$[88]$} \\
\hline OVA & QS-21 and deacylated QS-21 (DS-1) & Mice & $\begin{array}{c}\text { Despite DS-1 requiring a higher dose to induce IgG1 responses, it did } \\
\text { not induce IgG2a or CTL responses. Lower doses of QS-21 induced } \\
\text { higher IgG titers, including IgG2a and CTL responses. }\end{array}$ & [89] \\
\hline $\mathrm{FML}^{*}$ & Quil-A $^{\circledR}$ & Dogs & $\begin{array}{l}\text { The formulation protected dogs against canine kala-azar in the field } \\
\text { with robust immunogenicity. }\end{array}$ & {$[90]$} \\
\hline Measles virus & ISCOMs QA-22 & Rats and Macaques & $\begin{array}{l}\text { Vaccines induced high levels of antibodies, which showed no } \\
\text { decrease during a 2-year follow up. }\end{array}$ & [91] \\
\hline Herpes virus & Quillaja saponins & Mice & $\begin{array}{l}\text { Saponins' deacylation significantly reduced antibody production and } \\
\text { increased mortality rates during viral challenge test. }\end{array}$ & {$[92]$} \\
\hline $\begin{array}{l}\text { Opa J from Neisseria } \\
\text { meningitidis }\end{array}$ & Quil-A $^{\circledR}$ & Mice & $\begin{array}{l}\text { Quil- } A^{\circledR} \text { formulated with OpaJ was highly immunogenic, inducing } \\
\text { the production of Opa-specific antibodies. }\end{array}$ & [93] \\
\hline $\begin{array}{l}\text { Non-fimbrial adhesin } \\
\text { hemagglutinin B (HagB) }\end{array}$ & $\begin{array}{l}\text { Semi-synthetic saponin of Quillaja } \\
\text { GPI-0100 }\end{array}$ & Mice & $\begin{array}{l}\text { GPI-0100 showed better immunoadjuvancy than monophosphoryl } \\
\text { lipid A and alum, as a mucosal and systemic adjuvant, in inducing } \\
\text { serum anti-HagB. }\end{array}$ & [94] \\
\hline $\mathrm{FML}^{*}$ & Quil-A $^{\circledR}$ & Dogs & $\begin{array}{l}\text { The formulation was shown be effective in immunotherapy against } \\
\text { visceral leishmaniasis of asymptomatic infected dogs. All animals } \\
\text { showed significantly increased CD8 lymphocyte percentages. }\end{array}$ & [95] \\
\hline
\end{tabular}


Table 2. Cont.

\begin{tabular}{|c|c|c|c|c|}
\hline Antigen & Adjuvant & Model & Findings & Ref. \\
\hline $\begin{array}{l}\text { Human respiratory } \\
\text { syncytial virus (HRSV) }\end{array}$ & $\begin{array}{l}\text { HRSV-ISCOMs prepared with } \\
\text { Quillaja saponin fractions: QH-A; } \\
\text { QH-C; QH-A + QH-C (QH-AC) }\end{array}$ & Mice & $\begin{array}{l}\text { In general, the ISCOMs tested were well tolerated. However, the } \\
\text { combination of QH-A + QH-C ISCOMs was lethal in neonates } \\
\text { despite the QH-A or QH-C fractions alone being well tolerated. }\end{array}$ & [96] \\
\hline $\mathrm{FML}^{*}$ & $\begin{array}{l}\text { Quillaja saponaria sapogenins } \\
\text { containing aldehyde }\end{array}$ & Mice & $\begin{array}{l}\text { Vaccines elicited high levels of antibodies and cellular specific } \\
\text { response to FML and IFN } \gamma \text { sera levels and protection against } L \text {. } \\
\text { donovani murine infection was shown. }\end{array}$ & [97] \\
\hline Ovalbumin (OVA) & Quil-A $^{\circledR}$ & Mice & $\begin{array}{l}\text { Increasing amounts of Quil- } \mathrm{A}^{\circledR}(20 \% \text { to } 70 \%) \text { were tested in } \\
\text { liposomes. Higher doses of Quil A reduced the particle sizes formed, } \\
\text { thus decreasing antigen incorporation and uptake by DC. Liposomes } \\
\text { containing 20\% Quil- } \mathrm{A}^{\circledR} \text { were more effective as immunostimulants, } \\
\text { and more toxic in cell cultures too, when compared with those } \\
\text { containing 70\% Quil- } \mathrm{A}^{\circledR} \text {. }\end{array}$ & [98] \\
\hline $\begin{array}{l}\text { Mtb72F (Mycobacterium } \\
\text { tuberculosis) }\end{array}$ & AS02A & Mice & $\begin{array}{l}\text { Increase in both Th1 and Th2 response, with Th1 response being } \\
\text { more pronounced. }\end{array}$ & [99] \\
\hline LSP $P b C S 242-310$ ** & QS-21 & Mice & $\begin{array}{l}\text { The use of LSP } P b C S \text { 242-310 combined with QS- } 21 \text { induced a } \\
\text { satisfactory immune response similar to the one generated with the } \\
\text { injection of radiation-attenuated sporozoites. }\end{array}$ & [100] \\
\hline HRSV & $\begin{array}{l}\text { ISCOMs formulated with Quillaja } \\
\text { saponin fractions }\end{array}$ & Mice & $\begin{array}{l}\text { All three formulations favor Th1 responses to different degrees with } \\
\text { IFN-c being produced up to } 50 \text { times more than Il-4 and IL-5. The } \\
\text { HRSV } 703 \text { ISCOMs induced the most pronounced innate and } \\
\text { acquired response with the most prominent Th1 profile. }\end{array}$ & {$[101]$} \\
\hline $\begin{array}{l}\text { HIV-1 DNA } \\
\text { prime/protein-Env and } \\
\text { Gag *** }\end{array}$ & QS-21 & $\begin{array}{l}\text { Rhesus macaques and } \\
\text { mice }\end{array}$ & $\begin{array}{l}\text { Cellular and humoral responses were observed when Polyvalent } \\
\text { DNA prime/protein boost vaccine was administered. CD }{ }^{+} \text {CTL, } \\
\text { CD4 } 4^{+} \text {T-helper cells and Th1 cytokines were involved in cellular } \\
\text { immune response. }\end{array}$ & [102] \\
\hline FML * & $\begin{array}{l}\text { Fractions of the Riedel de Haen } \\
\text { saponin mixture (QS-21 saponin } \\
\text { fraction; two deacylsaponins mixture; } \\
\text { a mixture of glucose, rutin, quercetin, } \\
\text { and sucrose). }\end{array}$ & Mice & $\begin{array}{l}\text { QS-21 and the deacylsaponins induced the most significant reduction } \\
\text { of parasite burden in the liver, demonstrating a promising adjuvant } \\
\text { potential in the Riedel de Haen saponin mixture, which contains } \\
\text { deacylated saponins that are not toxic and induce robust immunity. }\end{array}$ & [103] \\
\hline $\begin{array}{l}\text { Plant-made measles virus } \\
\text { hemagglutinin (MV-H) } \\
\text { protein }\end{array}$ & $\begin{array}{l}\text { Cholera toxin (CTB/CT); LT(R192G) } \\
* * * * ; \text { Saponin extracted from Quillaja } \\
\text { bark (Sigma; S-4521) }\end{array}$ & Mice & $\begin{array}{c}\text { Despite both LT(R192G) and the crude saponins showing strong } \\
\text { adjuvant activity, the crude extract had superior immunostimulatory } \\
\text { properties. }\end{array}$ & {$[104]$} \\
\hline
\end{tabular}


Table 2. Cont.

\begin{tabular}{|c|c|c|c|c|}
\hline Antigen & Adjuvant & Model & Findings & Ref. \\
\hline $\begin{array}{l}\text { Fh15 (recombinant } 15 \mathrm{kDa} \\
\text { Fasciola hepatica protein) }\end{array}$ & ADAD System ***** & Mice and sheep & $\begin{array}{c}\text { Mice immunized with ADAD system with Qs had a survival rate of } \\
50-62.5 \% \text { while animals without Qs had a survival rate of } 40-50 \% \text {. } \\
\text { Sheep immunized with ADAD system with Qs showed less hepatic } \\
\text { damage compared to control group. }\end{array}$ & [105] \\
\hline $\mathrm{FML}^{*}$ & QS-21 & Dogs & $\begin{array}{c}\text { Despite nonspecific reactions being observed in the immunized } \\
\text { animals (similar to other veterinary vaccines), a significant decrease } \\
\text { was shown with subsequent doses. }\end{array}$ & [106] \\
\hline $\begin{array}{l}\text { LTB-ESAT- } 6 \text {; and Bacillus } \\
\text { Calmette-Guérin (BCG) }\end{array}$ & Quillaja extract & Mice & $\begin{array}{l}\text { Mice vaccinated with a combination of plant-made LTB-ESAT-6 } \\
\text { fusion BCG oral adjuvant had significantly more IL-10 production } \\
\text { when compared with mice vaccinated without adjuvant. However, } \\
\text { no protection was shown during the challenge test with M. } \\
\text { tuberculosis, in groups treated with oral BCG (with or without } \\
\text { saponin). }\end{array}$ & [107] \\
\hline GD3-KLH & GPI-0100 ••; sQS-21 ••• & Mice & $\begin{array}{l}\begin{array}{l}\text { Both synthetic Quillaja saponin molecules produced antibodies in } \\
\text { mice. }\end{array} \\
\text { ? }\end{array}$ & [108] \\
\hline $\begin{array}{l}\text { FALVAC-1A (different } \\
\text { epitopes from Plasmodium } \\
\text { falciparum) }\end{array}$ & $\begin{array}{l}\text { AIPO4, QS-21, Montanide ISA-720, or } \\
\text { CRL-1005 }\end{array}$ & Mice & $\begin{array}{l}\text { QS-21 was the second adjuvant that induced the most significant } \\
\text { levels of antibodies, inducing predominantly IgG2c. QS-21 also } \\
\text { induced the highest levels of IL-4 compared to the other adjuvants, } \\
\text { indicating Th1 and Th2 responses. }\end{array}$ & [109] \\
\hline $\mathrm{FML}^{*}$ & QS-21 & Dogs & $\begin{array}{l}\text { The vaccine induced robust immunogenicity with high levels of } \\
\text { FML-seroconversion, as demonstrated by CD8+ and CD4+ T cell } \\
\text { populations. }\end{array}$ & [110] \\
\hline $\begin{array}{l}\text { AD-472 } \cdots \text { or HSV-2 } \\
\text { glycoprotein D }\end{array}$ & GPI-0100 •• & Guinea pigs & $\begin{array}{l}\text { Both formulations reduced clinical disease; however, GPI-0100 } \\
\text { improved the glycoprotein-D formulation only. }\end{array}$ & [111] \\
\hline H9N2 & $\begin{array}{l}\text { Aluminium phosphate; aluminium } \\
\text { hydroxide; MF59 } \text {...»*; and }^{\text {MATRIX-M }}\end{array}$ & Mice & $\begin{array}{l}\text { MATRIX-M shifted the immune response to an IgG2a response } \\
\text { (towards a Th1 response). On the other hand, the CD8 } 8^{+} \text {T-cell } \\
\text { response could be improved using MATRIX-M or MF59. Among all } \\
\text { tested molecules, MATRIX-M was the most effective in inducing the } \\
\text { immune response, followed by MF59 and aluminium-based } \\
\text { adjuvants. }\end{array}$ & [112] \\
\hline HpaA and catalase & $\begin{array}{l}\text { ISCOMATRIX }^{\mathrm{TM}} \text {; ISCOM }{ }^{\mathrm{TM}} \text {; Cholera } \\
\text { toxin; and aluminium hydroxide }\end{array}$ & Mice & $\begin{array}{l}\text { ISCOMATRIXTM and ISCOMTM vaccines, using two different } \\
\text { antigens and different delivery systems (intranasal or subcutaneous), } \\
\text { have the same efficacy in reducing H. pylori colonization as the gold } \\
\text { standard cholera toxin (CT) adjuvant }\end{array}$ & [113] \\
\hline
\end{tabular}


Table 2. Cont

\begin{tabular}{|c|c|c|c|c|}
\hline Antigen & Adjuvant & Model & Findings & Ref. \\
\hline TA-CIN \#\# & GPI-0100 • & Mice and monkeys & $\begin{array}{l}\text { Prophylactic vaccination with adjuvanted TA-CIN protected the mice } \\
\text { from viral challenge, whereas vaccination without adjuvant was } \\
\text { almost ineffective. Moreover, GPI-0100 boosted IFN- } \gamma \text { secreting CD } 8^{+} \\
\text {T cell response in mice compared to the formulation without } \\
\text { adjuvant. Vaccination of macaques induced specific T cell responses. }\end{array}$ & {$[114]$} \\
\hline $\begin{array}{l}\text { Inactivated } \\
\text { Chlamydophila abortus }\end{array}$ & QS-21 & Mice & $\begin{array}{l}\text { The formulation induced the proliferation of B cells, which is } \\
\text { important to confer immunity to the bacteria rather than cellular } \\
\text { response. }\end{array}$ & [115] \\
\hline $\begin{array}{c}\text { sLEa }^{\mathrm{a}}-\mathrm{KLH} \\
\text { (glycolipid/glycoprotein } \\
\text { expressed on cancer cell } \\
\text { surface) }\end{array}$ & GP1-0100 & Mice & $\begin{array}{l}\text { Immunized animals produced high titers of highly reactive IgM and } \\
\text { IgG specific antibodies. }\end{array}$ & [116] \\
\hline Tetanus toxoid & $\begin{array}{l}\text { Quillaja saponins or cross-linked } \\
\text { dextran microspheres (CDM) }\end{array}$ & Rabbits & $\begin{array}{c}\text { Formulations with Quillaja saponins did not increase mucosal IgA. } \\
\text { On the other hand, the saponins induced the highest systemic IgG } \\
\text { titers. }\end{array}$ & [117] \\
\hline Ovalbumin & ISCOM matrices & Mice & $\begin{array}{l}\text { The formulation with ISCOMs induced high specificity CTLs } \\
\text { targeting different tumoral cells. }\end{array}$ & [118] \\
\hline $\begin{array}{l}\text { Tetanus toxoid loaded } \\
\text { onto PLGA nanospheres }\end{array}$ & Quillaja saponins, CDM & Rabbits & $\begin{array}{l}\text { The combination of Quillaja saponins with CDM in PLGA } \\
\text { nanospheres loaded with antigens improved IgA production, } \\
\text { suggesting better mucosal protection. The same was observed with } \\
\text { systemic IgG. }\end{array}$ & [119] \\
\hline $\begin{array}{l}\text { Inactivated Bovine } \\
\text { herpesvirus-5 }\end{array}$ & $\begin{array}{l}\text { Aluminum hydroxide, Quil-A }{ }^{\circledR} \text {, or } \\
\text { QB-90 (from Quillaja brasiliensis) }\end{array}$ & Mice & $\begin{array}{c}\text { Quil- }^{\circledR} \text { and QB-90 induced similar immunity regarding humoral or } \\
\text { cellular responses. }\end{array}$ & [27] \\
\hline ALM (Leishmania major) & $\begin{array}{l}\text { PLGA nanoparticles containing } \\
\text { purified saponin extract }\end{array}$ & Mice & Increase in both Th1 andTh2 response. & {$[120]$} \\
\hline $\begin{array}{l}\text { HIV-1 gp120 with Q105N } \\
\text { mutation }\end{array}$ & Quil-A $^{\circledR}$ or MPL & Mice & $\begin{array}{l}\text { Despite both adjuvants producing specific antibodies, there was no } \\
\text { significant neutralizing activity against HIV-1. }\end{array}$ & {$[121]$} \\
\hline Tetanus toxoid & Quillaja saponins & Rabbits & $\begin{array}{l}\text { Quillaja formulation was more efficient in conferring mucosal } \\
\text { protection due to increased levels of IgA. }\end{array}$ & [122] \\
\hline No antigen was used & $\begin{array}{l}\text { Alhydrogel or MATRIX-M }{ }^{\mathrm{TM}} \\
\text { formulated with fractions of Q. } \\
\text { saponaria }\end{array}$ & Mice & $\begin{array}{l}\text { Besides stimuli caused by MATRIX-M }{ }^{\mathrm{TM}} \text { during the immune } \\
\text { response (increase in cell recruitment and cytokine secretion), it } \\
\text { induced the expression of co-stimulatory molecule CD86, } \\
\text { participating in early events of the immune response. }\end{array}$ & [123] \\
\hline $\begin{array}{l}\text { Rhoptry Toxoplasma } \\
\text { gondii protein }\end{array}$ & Quil-A $^{\circledR}$ & Swine & $\begin{array}{l}\text { The formulation induced high humoral, local, and systemic immune } \\
\text { response, partially preventing brains from forming cysts. }\end{array}$ & [124] \\
\hline
\end{tabular}


Table 2. Cont

\begin{tabular}{|c|c|c|c|c|}
\hline Antigen & Adjuvant & Model & Findings & Ref. \\
\hline $\begin{array}{l}\text { Tetanus toxoid loaded } \\
\text { onto chitosan } \\
\text { functionalized gold } \\
\text { nanoparticles }\end{array}$ & Quillaja saponins & Mice & $\begin{array}{l}\text { When administered orally, the nanoparticles can better deliver the } \\
\text { formulation, increasing immune response up to } 28 \text {-fold compared to } \\
\text { control. }\end{array}$ & {$[125]$} \\
\hline HIV-1 gp120 & $\begin{array}{l}\text { QS-21, aluminum hydroxide, MPLA, } \\
\text { or ISCOMATRIX }{ }^{\mathrm{TM}}\end{array}$ & Mice & $\begin{array}{l}\text { Each adjuvant stimulated a different cytokine profile secretion, } \\
\text { having different properties in the induction of the inflammation. }\end{array}$ & [126] \\
\hline $\begin{array}{l}\text { MUC1-KLH (prostate } \\
\text { cancer marker) and/or } \\
\text { ovalbumin }\end{array}$ & $\begin{array}{l}\text { QS-21, synthetic QS-21, or other } \\
\text { conjugated saponins }\end{array}$ & Mice & $\begin{array}{l}\text { Despite QS-21 inducing robust Th1 and Th2 response, conjugated } \\
\text { saponins had improved activity and toxicity profiles relative to } \\
\text { QS-21. }\end{array}$ & [127] \\
\hline $\begin{array}{l}\text { Varicella zoster } \\
\text { glycoprotein E and } \\
\text { ovalbumin }\end{array}$ & AS01 & Mice & $\begin{array}{l}\text { AS01 can improve adaptive humoral response through the } \\
\text { generation of a great number of antigen-presenting cells. }\end{array}$ & [128] \\
\hline Inactivated Poliovirus & $\begin{array}{l}\text { Quil-A }{ }^{\circledR}, \mathrm{QB}-90 \text {, and Aqueous Extract } \\
\quad \text { from Quillaja brasiliensis }\end{array}$ & Mice & $\begin{array}{l}\text { The humoral enhancements caused by Quil- } \mathrm{A}^{\circledR} \text { and QB- } 90 \text { were } \\
\text { statistically similar. However, the mucosal immune response was } \\
\text { increased with QB-90 by increases in IgA. }\end{array}$ & [26] \\
\hline $\begin{array}{l}\text { Tau antigen (associated } \\
\text { with Alzheimer's disease) }\end{array}$ & Quil-A $^{\circledR}$ & Mice & $\begin{array}{c}\text { Animals that received the formulations with Quil- } \mathrm{A}^{\circledR} \text { had reduced } \\
\text { neuroinflammation and tau pathogenesis. }\end{array}$ & [129] \\
\hline $\begin{array}{l}\text { MARV-VLP (Marburg virus } \\
\text { virus-like particle } \\
\text { containing glycoprotein, } \\
\text { matrix vp40, and } \\
\text { nucleoprotein) }\end{array}$ & QS-21 or polyI:C & Cynomolgus macaques & $\begin{array}{l}\text { Formulations prepared with either of the adjuvants provided full } \\
\text { protection in the challenge test. QS- } 21 \text { produced a lower response to } \\
\text { antigens compared to polyI:C. }\end{array}$ & {$[130]$} \\
\hline $\begin{array}{l}\text { EBOVgp-Fc (Ebola virus } \\
\text { glycoprotein fused to Fc } \\
\text { fragment of human IgG1) }\end{array}$ & $\begin{array}{l}\text { QS-21, aluminum hydroxide, or } \\
\text { poly-ICLC }\end{array}$ & Guinea pigs & $\begin{array}{l}\text { All formulations induced antibody formation, however, despite } \\
\text { QS-21 inducing a strong humoral response, in the challenge test only } \\
\text { poly-ICLC induced robust protection. }\end{array}$ & [131] \\
\hline $\begin{array}{l}\text { Intanza } 2013 \text { (Trivalent } \\
\text { Influenza Vaccine, Sanofi } \\
\text { Pasteur) }\end{array}$ & QS-21 & Mice & $\begin{array}{l}\text { When administered in the skin as a Nanopatch vaccine, a lower dose } \\
\text { of QS-21 and adjuvant was required to enhance humoral response } \\
\text { compared to intramuscular administration. }\end{array}$ & [132] \\
\hline $\begin{array}{l}\text { Ovalbumin or HBsAg } \\
\text { (Hepatitis B virus surface } \\
\text { antigen) }\end{array}$ & QS-21 liposome & Mice & $\begin{array}{l}\text { The immunoadjuvancy of QS-21 relies on macrophages to induce } \\
\text { activation of dendritic cells and stimulate the immune system. }\end{array}$ & [133] \\
\hline $\begin{array}{l}\text { FhSAP2-IBs (Fasciola } \\
\text { hepatica protein) }\end{array}$ & QS-21 or Montanide ISA720 & Mice & $\begin{array}{l}\text { Increase in both Th1 and Th2 responses with significant increase in } \\
\text { Th1 response. }\end{array}$ & {$[134]$} \\
\hline
\end{tabular}


Table 2. Cont.

\begin{tabular}{|c|c|c|c|c|}
\hline Antigen & Adjuvant & Model & Findings & Ref. \\
\hline $\begin{array}{l}\text { QS-21 or QS-21 } \\
\text { formulated with HIV-1 } \\
\text { gp120 }\end{array}$ & QS-21 & Mice & QS-21 activates NLRP3 inflammasome. & [21] \\
\hline $\begin{array}{l}\text { Inactivated bovine viral } \\
\text { diarrhea virus }\end{array}$ & $\begin{array}{l}\text { Saponins of Q. brasiliensis (QB-90) and } \\
\text { Q. brasiliensis aqueous extract (AE) }\end{array}$ & Mice & $\begin{array}{l}\text { In vaccines adjuvanted with } \mathrm{QB}-90 \text { and } \mathrm{AE} \text { higher levels of antibody } \\
\text { were detected. Animals that received QB-90 adjuvanted vaccine had } \\
\text { enhanced cytokines and IFN- } \gamma \text { production by } \mathrm{CD} 4+\text { andCD8+T } \\
\text { lymphocytes whereas AE-adjuvanted preparation stimulated } \\
\text { humoral response only. }\end{array}$ & [135] \\
\hline Ovalbumin & $\begin{array}{l}\text { ISCOMs of Q. brasiliensis saponin } \\
\text { fraction (IQB-90) and Quil- }{ }^{\circledR} \\
\text { ISCOMs }\end{array}$ & Mice & $\begin{array}{l}\text { IQB-90 inoculated subcutaneously induced strong antibody response } \\
\text { (IgG1and IgG2a) and increased Th1 response. IQ-90 delivered } \\
\text { intranasally induced secretion of serum IgG and IgG1 and mucosal } \\
\text { IgA. }\end{array}$ & [25] \\
\hline No antigen was used & MATRIX-M ${ }^{\mathrm{TM}}$ & Swine & $\begin{array}{l}\text { MATRIX-M }{ }^{\mathrm{TM}} \text { formulation induced pro-inflammatory cytokines, } \\
\text { suggesting enhancement of innate immune response of specific } \\
\text { pathogen free pigs exposed to reared pigs. }\end{array}$ & [68] \\
\hline $\begin{array}{l}\text { A } \beta 42 \text { (Alzheimer's } \\
\text { disease pathological } \\
\text { hallmark) }\end{array}$ & QS-21 & Rhesus monkeys & $\begin{array}{l}\text { The formulation induced a good humoral response with high titers of } \\
\text { IgG and IgA. No inflammatory cellular immune response was } \\
\text { observed. }\end{array}$ & [136] \\
\hline $\begin{array}{l}\text { Ovalbumin and HBsAg } \\
\text { (Hepatitis B virus surface } \\
\text { antigen) }\end{array}$ & QS-21 & $\begin{array}{l}\text { In vitro (THP-1 cell) and } \\
\text { mice }\end{array}$ & $\begin{array}{l}\text { Human monocyte-derived dendritic cells were directly activated by } \\
\text { QS-21, requiring cathepsin B to induce high CD4 and CD8 T cell } \\
\text { response. }\end{array}$ & [137] \\
\hline $\begin{array}{l}\text { FMP013 (Falsiparum } \\
\text { Malaria Protein-013 from } \\
\text { Plasmodium falciparum) }\end{array}$ & $\begin{array}{c}\text { ALF, ALF + aluminum hydroxide, } \\
\text { ALFQ + QS-21, or Montanide ISA720 }\end{array}$ & Mice & $\begin{array}{l}\text { The ALF adjuvant conjugated with QS-21 induced the highest } \\
\text { antibody titer with the highest IgG2c titers. Also, it augmented the } \\
\text { number of activated B-cells compared to Montanide. }\end{array}$ & [138] \\
\hline HBsAg & QS-21 liposome & Swine & $\begin{array}{l}\text { The study demonstrated that the HBsAg formulated with QS-21 } \\
\text { liposomes in dissolvable microneedle arraypatches induced similar } \\
\text { immunization to the commercial HBsAg formulation. }\end{array}$ & [139] \\
\hline $\begin{array}{c}\text { Inactivated Bovine Viral } \\
\text { Diarrhea Virus }\end{array}$ & $\begin{array}{l}\text { QB-90 and IMXQB- } 90 \text { (ISCOMs and } \\
\text { Q. brasiliensis saponins }\end{array}$ & Mice & $\begin{array}{l}\text { The use of Q. brasiliensis saponins in vaccine formulations either } \\
\text { formulated in ISCOM structures or not promoted a satisfactory and } \\
\text { promising immune response, similar to Quil-A®. }\end{array}$ & [140] \\
\hline
\end{tabular}


According to Table 2, saponins can be formulated with a variety of antigens, either by pathogens or human proteins, and elicit a strong immune response, generally geared towards a humoral response [137]. Interestingly, over time there has been an increase in the number of studies using QS-21 rather than Quil-A ${ }^{\circledR}$ or Quillaja extracts, probably due to its reduced toxicity [141]. Meanwhile, the chemical instability of QS-21 is reflected by acyl side chain hydrolysis, which occurs spontaneously in aqueous solutions at room temperature [142], so studies of the structure-activity relationship have been performed to enhance its adjuvant activity and reduce the undesirable effects $[90,103,127]$. QS-21 deacylation at Fuc-C4 was critical for Th1-type response but it was not so important for Th2-type response [90,142].

The combination of Quillaja saponins with other immunostimulants and formulation with carriers can take advantage of different delivery systems, such as nanoparticles [124], ISCOMs [25,86,91,96,101,113,126], ISCOM Matrix [88,113,123] and liposomes [133] for intranasal [117] or subcutaneous injections.

In Table 2 over 60 pre-clinical studies for infectious diseases, degenerative disorders, and cancer are reported. For human infectious diseases the most tested antigen was Fucose-Mannose-Ligand (FML) antigen from Leishmania (L.) donovani $[90,95,97,103,106,110]$. Other vaccines for infectious diseases have also been well studied, such as hepatitis B [133,137,139], malaria [113,142], and HIV-1 [21,121,126] For veterinary use, pre-clinical trials have focused on Bovine Herpes Virus-5 [27] and Bovine Viral Diarrhea Virus [25,143] Fewer studies have been reported for degenerative disorders (Alzheimer's disease) $[129,136]$ and oncology $[116,127]$. In view of the amount of studies and the promising findings, many clinical trials have been developed, as mentioned in Table 4.

Most clinical trials test the safety and efficacy of the formulations. Although Quil- $\mathrm{A}^{\circledR}$ and other Quillaja saponins have been used in pre-clinical studies, only one study reported Quillaja saponins for human use [144]. In all other studies, only QS-21 has been evaluated for human use [142,144-148]. QS-21 has been tested in prophylactic vaccines for treatment of malaria. A phase III clinical trial was conducted to determine the efficacy, safety, and immunogenicity of the RTS/S ASO1 vaccine and received positive regulatory approval from $\mathrm{WHO}$, which recommended more evaluations before high level introduction in Africa, where the clinical study was conducted. Prophylactic vaccines have been tested using gp120 protein from HIV-I [149] and hepatitis B virus surface antigen [150].

QS-21 has been used in therapeutic vaccines to treat cancer patients. In these cases, instead of being administered in healthy people, the vaccine formulation needs to induce immune responses against existing tumors $[83,145,146,151,152]$. A more important experiment using QS-21 in therapeutic vaccines occurred after a surgical procedure in patients in stage II melanoma. The vaccine was well tolerated, and robust antibody responses were obtained [142,145]. 
Table 3. Clinical trials using Quillaja saponins as an adjuvant in vaccine formulations.

\begin{tabular}{|c|c|c|c|c|}
\hline Antigen & Adjuvant & Objective & Findings & Ref. \\
\hline $\begin{array}{l}\text { CHO-derived gp120 protein } \\
\text { from HIV-1 }\end{array}$ & $\mathrm{QS}-21$ or $\mathrm{Al}(\mathrm{OH})_{3}$ & $\begin{array}{c}\text { Evaluate safety and assess kinetics of immune } \\
\text { response }\end{array}$ & $\begin{array}{c}\text { Improved T cell response inducing CTL activation } \\
\text { with T helper cells was observed in formulations with } \\
\text { QS-21. }\end{array}$ & [149] \\
\hline $\begin{array}{l}\text { Globo H-KLH (carbohydrate } \\
\text { antigen found in most breast } \\
\text { cancer cells) }\end{array}$ & QS-21 & $\begin{array}{l}\text { Determine the formulation toxicity against } \\
\text { cancerous cells, its immune response, and if } \\
\text { the conjugation of Globo H with KLH would } \\
\text { affect the immune response }\end{array}$ & $\begin{array}{l}\text { Increase in specific antibody production and increased } \\
\text { cytotoxicity either from complement system or } \\
\text { antibody signaling. }\end{array}$ & {$[145]$} \\
\hline $\begin{array}{l}\text { PolySA and NP-polySA both } \\
\text { conjugated with KLH (protein } \\
\text { that in adults is associated with } \\
\text { small cell lung cancer) }\end{array}$ & QS-21 & $\begin{array}{l}\text { Determine the immune response after } \\
\text { vaccination and assess the impact of polySA } \\
\text { chemical manipulation }\end{array}$ & $\begin{array}{l}\text { NP-polySA vaccination resulted in higher antibody } \\
\text { titers with IgM response. The IgM was reactive to } \\
\text { small cell lung cancer. }\end{array}$ & [146] \\
\hline MUC-2G/Globo H-KLH & $\begin{array}{c}\text { GPI-0100•; GPI-0100-P } \\
\bullet ; \text { QS-21 }\end{array}$ & $\begin{array}{l}\text { Present the use of GPI- } 0100 \text { in humans and } \\
\text { determine the safety and immunogenicity of a } \\
\text { vaccine with different doses of GPI- } 0100 \text {. }\end{array}$ & $\begin{array}{l}\text { GPI-0100 }(5000 \mu \mathrm{g}) \text { and QS-21 }(100 \mu \mathrm{g}) \text { produced } \\
\text { comparable antibody titers. All adjuvanted vaccine } \\
\text { doses were well tolerated and antigen-specific } \\
\text { antibody titers matched increasing dose levels. }\end{array}$ & [83] \\
\hline $\mathrm{SL}^{*}$ & AS02A $\cdots$ & $\begin{array}{l}\text { Evaluate the potential of an AS02A adjuvanted } \\
\text { formulation in healthy individuals and } \\
\text { compare it to a non-adjuvanted vaccine. }\end{array}$ & $\begin{array}{l}\text { The adjuvanted vaccine induced more significative } \\
\text { humoral and Th1 immune responses compared with } \\
\text { the non-adjuvanted formulation. Despite the AS02A } \\
\text { recipients reporting local and general reactions more } \\
\text { frequently than the non-adjuvanted group, the safety } \\
\text { profile was acceptable. }\end{array}$ & [153] \\
\hline FMP1 ** & $\begin{array}{l}\text { AS02A (oil-in-water } \\
\text { formulation with } \\
\text { mono- phosphoryl } \\
\text { lipid A and QS-21 }\end{array}$ & $\begin{array}{l}\text { Evaluate the safety and immunogenicity of } \\
\text { malaria vaccine FMP1/AS02A in adults }\end{array}$ & $\begin{array}{l}\text { FMP1 formulated with AS02A was well tolerated and } \\
\text { showed high immunogenicity with specific } \\
\text { anti-MSP-142 antibody titers boosted and prolonged } \\
\text { due to the vaccination. }\end{array}$ & [147] \\
\hline Influenza & QS-21 & $\begin{array}{l}\text { Evaluate QS21 as an adjuvant and compare it } \\
\text { with standard trivalent inactivated influenza }\end{array}$ & $\begin{array}{l}\text { Local pain and post vaccination myalgias were greater } \\
\text { in individuals that received QS-21. Despite increased } \\
\text { serum antibodies, the mean titers for formulations } \\
\text { (with or without QS-21) were not different. }\end{array}$ & [148] \\
\hline $\begin{array}{l}\text { RTS,S (recombinant proteins } \\
\text { from P. falciparum) }\end{array}$ & AS02D & $\begin{array}{l}\text { Evaluate the immunogenicity of RTS,S/AS02D } \\
\text { formulation (liquid and lyophilized) }\end{array}$ & $\begin{array}{l}\text { Lyophilized formulation is as efficient and safe as the } \\
\text { liquid formulation, promoting satisfactory } \\
\text { immunization. }\end{array}$ & {$[154]$} \\
\hline
\end{tabular}


Table 4. Clinical trials using Quillaja saponins as an adjuvant in vaccine formulations.

\begin{tabular}{|c|c|c|c|c|}
\hline Antigen & Adjuvant & Objective & Findings & Ref. \\
\hline PfAMA1 *** & $\begin{array}{c}\text { Alhydrogel }{ }^{\mathrm{TM}}, \\
\text { Montanide ISA720 and } \\
\text { AS02 Adjuvant System }\end{array}$ & $\begin{array}{l}\text { Evaluate the immunogenicity and safety of } \\
\text { PfAMA1 antigen (two different doses with } \\
\text { three different adjuvants) }\end{array}$ & $\begin{array}{l}\text { All formulations caused different reactogenicity with } \\
\text { no serious reported adverse effects. All formulations } \\
\text { tested induced antibody production, with AS02 being } \\
\text { the most pronounced. }\end{array}$ & [155] \\
\hline RTS,$S^{* * * *}$ & AS02A & $\begin{array}{l}\text { Determine the safety of the RTS,S antigen } \\
\text { formulated with AS02A adjuvant. }\end{array}$ & $\begin{array}{l}\text { The formulation was well tolerated in children, with a } \\
\text { good safety profile within the number of doses. The } \\
\text { AS02A formulation caused fewer serious adverse } \\
\text { events compared to the control group. }\end{array}$ & [156] \\
\hline FMP2.1 $1^{* * * * *}$ & AS02A & $\begin{array}{l}\text { Evaluate the reactogenicity, safety, and } \\
\text { immunogenicity of the malaria vaccine } \\
\text { FMP2.1/AS02A in adults. }\end{array}$ & $\begin{array}{l}\text { The formulation was well tolerated and showed good } \\
\text { safety. Also, it was highly immunogenic. }\end{array}$ & [157] \\
\hline No antigen was used & Quillaja saponins & $\begin{array}{l}\text { Determine if dietary QS can modify } \\
\text { macrophage activity and investigate its effects } \\
\text { on liver function and inflammatory response }\end{array}$ & $\begin{array}{l}\text { An increase in chemotactic and phagocytosis activities } \\
\text { were observed. Furthermore, no adverse effects were } \\
\text { seen since no significant changes in immunoglobulin, } \\
\text { transaminase, IL- } 1 \alpha \text {, and TNF- } \alpha \text { were observed. }\end{array}$ & [144] \\
\hline $\begin{array}{l}\text { NP-polySA-KLH (Polysialic } \\
\text { acid conjugated to keyhole } \\
\text { limpet hemocyanin (KLH)) }\end{array}$ & QS-21 & $\begin{array}{c}\text { Confirm the safety profile and determine the } \\
\text { optimal dose }\end{array}$ & $\begin{array}{c}\text { The lowest optimal immunogenic dose was } 10 \mu \mathrm{g}, \\
\text { which resulted in consistent high-titer antibody } \\
\text { responses. }\end{array}$ & [151] \\
\hline $\begin{array}{l}\text { MAGE-A3 (tumor-specific } \\
\text { protein usually expressed in } \\
\text { melanoma) }\end{array}$ & AS02B or AS15 & $\begin{array}{l}\text { Discover which adjuvant would cause a more } \\
\text { robust and persistent immune response }\end{array}$ & $\begin{array}{l}\text { AS15 provided a more robust immune response by } \\
\text { activating more dendritic and B cells. }\end{array}$ & [152] \\
\hline $\begin{array}{l}\text { HBsAg (Hepatitis B virus surface } \\
\text { antigen) }\end{array}$ & $\begin{array}{l}\text { AS02B, AS02V, or } \\
\text { AS01B }\end{array}$ & $\begin{array}{l}\text { Evaluate the duration of humoral and cellular } \\
\text { responses }\end{array}$ & $\begin{array}{l}\text { All formulations induced persistent T CD4+ and CD8+ } \\
\text { specific response, as well as B-cell response, indicating } \\
\text { immunological memory. }\end{array}$ & [150] \\
\hline $\begin{array}{l}\text { Unimolecular conjugated } \\
\text { Globo-H, GM2, sTn, TF, and Tf } \\
\text { (markers usually expressed on } \\
\text { ovarian cancer cell-surface) }\end{array}$ & QS-21 & $\begin{array}{l}\text { Evaluate safety and immunogenicity of the } \\
\text { pentavalent synthetic vaccine }\end{array}$ & $\begin{array}{l}83 \% \text { of individuals responded to at least three antigens } \\
\text { with satisfactory immune response. }\end{array}$ & [158] \\
\hline $\begin{array}{c}\text { HBsAg (surface antigen of } \\
\text { Hepatitis B virus), ovalbumin, } \\
\text { CSP (P. falciparum } \\
\text { circumsporozoite protein), and } \\
\text { Varicella zoster glycoprotein E }\end{array}$ & AS01 & $\begin{array}{c}\text { Investigate how combining } \\
\text { immune-stimulants results in innate immune } \\
\text { response }\end{array}$ & $\begin{array}{l}\text { AS01 triggers innate response, such as NK-cells, and } \\
\text { activates CD8 T-cells in the lymph nodes, depending } \\
\text { on macrophage, IL-12, and IL-18. }\end{array}$ & [159] \\
\hline
\end{tabular}

- GPI-0100: Semi synthetic analogue of Quillaja saponin; $\bullet$ GPI-0100P: GPI-0100 purified; $\cdots$ AS02A: oil-in-water formulation containing monophosphoryl lipid A and QS-21; * SL: recombinant hepatitis B protein containing the small protein $(\mathrm{S})$ and the modified large (L) protein of the hepatitis B viral envelope, containing pre-Sl and pre-S2 sequences in addition to the entire S sequence. ${ }^{* *}$ FMP1 (Falciparum malaria protein 1): recombinant protein based on the carboxy-terminal end of merozoite surface protein-1 (MSP-142) from the 3D7 clone of $P$.

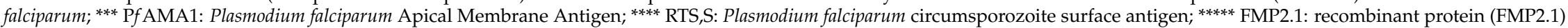
based on Apical Membrane Antigen-1 (AMA-1) from the 3D7 clone of P. falciparum. 


\section{Toxicity of Quillaja Saponins}

Regarding the toxicity of $Q$. saponaria and Q. brasiliensis, there are few studies in the literature. The studies available focus on the preclinical toxicity evaluation. One of the first studies to address the toxicity of Q. saponaria and its fractions was published in 1995, by Rönnberg et al. [160]. This study evaluated the toxicity of crude Q. saponaria extract and QH-A, QH-B, and QH-C purified triterpenoid components in WEHI cells (immature B-lymphocytes of Mus musculus). The evaluation of the lytic activities of $Q$. saponaria, responsible for the local reactions after injection, demonstrated that $\mathrm{QH}-\mathrm{A}$ was safer than QH-B and QH-C, causing hemolysis only at a concentration ten-times higher. In addition, QH-B and QH-C did not affect RNA or protein synthesis, suggesting that they are not the primary toxicity targets. Similarly, hydrolyzed saponins of $Q$. saponaria, resulting in deacylated forms, have significantly reduced the toxicity of the substance. This supports the role of fatty acids in the toxic activity of saponins [161]. Thought-provokingly, none of the Quillaja saponins presented hemolytic activity after incorporation into the ISCOM matrix [160].

Although QH-B has a strong adjuvant effect, it represents the most toxic triterpenoid saponin, thus limiting its application in vitro and in vivo. Rönnberg et al. [162] demonstrated that a 10-fold higher QH-B concentration treated with sodium periodate reduced the enzymatic activities of the cells exposed to QH-B without sodium periodate by a factor of ten. The QH-B toxicity reduction is possibly the result of changes in the sugars' chemical structure, such as xylose and galactose $[160,162]$. Similarly, hydrolyzed saponins of $Q$. saponaria, resulting in deacylated forms, have significantly reduced the toxicity of the substance. This supports the role of fatty acids in the toxic activity of saponins [161].

Arabski et al. [46] also studied the in vitro toxicity of Q. saponaria, but in the CHO-K1 cell line (cells from the ovary of Cricetulus griseus). They demonstrated that the saponins significantly increased death in this cell line by early apoptosis, at doses ranging from 12 to $50 \mu \mathrm{g} / \mathrm{mL}$. Minor doses were not able to lyse the exposed erythrocytes, elucidating the minimal concentration required to intersperse with cell membranes in order to lyse them.

Quillaja saponin toxicity has also been studied in alternative mammalian models and in vivo models. Abdula et al. [163] evaluated the effects of $Q$. saponaria saponins regarding lethality and alterations in Danio rerio morphology during the first 3 days. This invertebrate, also known as zebrafish, is an important alternative to mammalian tests and is effective for studying toxicity mechanisms. The results showed that $Q$. saponaria presented both harmful and beneficial effects on the embryos of zebrafish, since a $5 \mu \mathrm{g} / \mathrm{mL}$ concentration promoted growth and a $10 \mu \mathrm{g} / \mathrm{mL}$ concentration was mortal to zebrafish. These findings suggest that the toxic effects of $Q$. saponaria saponins could affect the semipermeable protective chorion expressed by the embryo in development. Alternatively, it could affect cells in the embryo bodies, by permeating the noncellular chorion.

The toxicity of Quillaja extracts and their saponin derivatives was also studied in neonates of the aquatic crustacean D. magna and in D. rerio zebrafish embryos [164]. The authors demonstrated that Quillaja extract and Q. saponaria fractions QS-18 (35.1 $\pm 4.1 \%$ of the total Quillaja saponins) and QS-21 (3.7 $\pm 0.3 \%)$ have similar toxicity; nevertheless, with a toxicity potential three to eight times higher than non-saponins. Thus, Quillaja saponins contribute to the majority of the toxicity (85.1-93.6\%), with QS-21 being slightly more toxic than QS-18. The non-saponins contribute to only 14 and 6\%. The higher lipophilicity of QS-18 and QS-21 is probably responsible for their higher toxicity, since lipophilic substances can easily cross the embryo chorion, resulting in a higher uptake in zebrafish embryos [165].

In vivo Quillaja extract acute toxicity was studied by Tam and Roner [8]. They orally treated newborn mice with $50 \mu \mathrm{L}$ of saponin extract. The concentrations ranged from 0 to $0.5 \mathrm{mg} / \mathrm{mouse}$. The animals were treated for seven days and observed for two months. The $0.0375 \mathrm{mg} / \mathrm{mouse}$ dose presented more than $50 \%$ mortality, thus the $\mathrm{LD}_{50}$ of the extract was established at $0.0325 \mathrm{mg} / \mathrm{mouse}$. The weight evaluation demonstrated that there was no short-term health impact in mice that survived treatment with saponins. On the other hand, the high concentrations of the extract killed the mice 
within 24-36 h, suggesting an important alteration in the membrane environment of the gastrointestinal tract, leading cells to burst.

Finally, Vinai et al. [166] studied the safe dose of vaccine adjuvants, such as Quillaja saponins, for intra-peritoneal vaccination. Flounder fingerlings were acutely treated and lethality and toxicity signs, such as body color, feeding, and swimming behavior, were evaluated. The group treated with saponins showed different toxicity levels, according to the concentrations tested. The toxicity signs observed were fish lethargy, body color alterations, and alterations in feeding behavior; the liver and intestine presented important hemorrhages, the fish showed pale gills, and the peritoneal cavity was filled with red ascites, suggesting high toxicity of the highest dose tested. In this study, Quillaja saponins presented a $\mathrm{LD}_{50}$ of $105 \mu \mathrm{g} /$ fish $(22.4 \mathrm{mg} / \mathrm{kg})$, reinforcing the high toxicity. In addition, they caused severe histological damage, as well as liver damage, observed by the increase in AST level at doses above $16 \mu \mathrm{g} /$ fish and of ALT at $160 \mu \mathrm{g} /$ fish.

In clinical studies only QS-21 toxicity have been studied. For most patients the dose-limiting toxicity is about $50 \mu \mathrm{g} /$ dose, except for cancer patients (100-200 $\mu \mathrm{g}$ per vaccination) [142]. Therefore, the safety of Quillaja saponins is still not well established and more studies are necessary.

\section{Conclusions}

Quillaja saponins have been employed in the food industry as emulsifiers for beverages and food additives. In the cosmetic industry, they have been used as antidandruff, cleansing, emulsifying, foaming, masking, moisturizing, skin conditioning, and surfactant agents. However, these are not the only applications of Quillaja saponins. The particular chemical characteristics of these metabolites, along with their biological activities, show potential for drug discovery and vaccines development. Most of these saponins are bidesmosides and contain a triterpenic aglycone belonging to the b-amyrin series, most frequently quillaic acid. Vaccine adjuvation is the main propriety studied for Quillaja saponins, which have shown potent immunogenic activity and the ability to modulate immunity towards a cell-mediated response or to enhance antibody production. In addition to improving immunoadjuvant activity and minimizing their toxicity, these saponins are been evaluated in different formulations, such as ISCOMs, oil-in-water formulations, and liposomes, among others.

Furthermore, studies have demonstrated antiviral (herpes simplex virus type 1, human immunodeficiency viruses 1 and 2, varicella zoster virus, vaccinia virus, rhesus rotavirus, and reovirus), antifungal (Penicillium roguefortii, Aspergillus ochraceus, Alternaria solani, Fusarium oxysporum, Verticillium dahlia, and Pythium ultimum), and antibacterial (Staphylococcus aureus, Salmonella typhimurium, and Asaia spp.) activities for Quillaja saponins. However, their activity against E. coli is not established, since different commercial extracts of Quillaja saponins have shown opposing results. Studies have also demonstrated antiparasitic (in vitro), antitumor (in vitro and in vivo), and hepatoprotective (in vivo) activities. Regarding toxicity, there are few studies in the literature, which focuses on evaluating preclinical toxicity and lacks clinical studies.

Author Contributions: All the authors collaborated in the writing of the present work and approved its submission.

Funding: This research received no external funding.

Conflicts of Interest: The authors declare no conflict of interest.

\section{References}

1. Sparg, S.G.; Light, M.E.; Van Staden, J. Biological activities and distribution of plant saponins. J. Ethnopharmacol. 2004, 94, 219-243. [CrossRef]

2. Augustin, J.M.; Kuzina, V.; Andersen, S.B.; Bak, S. Molecular activities, biosynthesis and evolution of triterpenoid saponins. Phytochemistry 2011, 72, 435-457. [CrossRef] [PubMed]

3. Higuchi, R.; Tokimitsu, Y.; Komori, T. An acylated triterpenoid saponin from Quillaja saponaria. Phytochemistry 1988, 27, 1165-1168. [CrossRef] 
4. Nord, L.I.; Kenne, L. Novel acetylated triterpenoid saponins in a chromatographic fraction from Quillaja saponaria Molina. Carbohydr. Res. 2000, 329, 817-829. [CrossRef]

5. Sun, H.-X.; Xie, Y.; Ye, Y.-P. Advances in saponin-based adjuvants. Vaccine 2009, 27, 1787-1796. [CrossRef]

6. Codex Alimentarius International Food Standards; Food and Agriculture Organization of United Nations World Health Organization: Rome, Italy, 2018; Volume 49.

7. Wojciechowski, K. Surface activity of saponin from Quillaja bark at the air/water and oil/water interfaces. Colloids Surfaces B Biointerfaces 2013, 108, 95-102. [CrossRef] [PubMed]

8. European Commission Database-CosIng. Available online: http://ec.europa.eu/growth/sectors/cosmetics/ cosing_en (accessed on 12 December 2018).

9. Ozturk, B.; McClements, D.J. Progress in natural emul sifiers for utilization in food emulsions. Curr. Opin. Food Sci. 2016, 7, 1-6. [CrossRef]

10. de Faria, J.T.; de Oliveira, E.B.; Minim, V.P.R.; Minim, L.A. Performance of Quillaja bark saponin and $\beta$-lactoglobulin mixtures on emulsion formation and stability. Food Hydrocoll. 2017, 67, 178-188. [CrossRef]

11. Roner, M.R.; Sprayberry, J.; Spinks, M.; Dhanji, S. Antiviral activity obtained from aqueous extracts of the Chilean soapbark tree (Quillaja saponaria Molina). J. Gen. Virol. 2007, 88, 275-285. [CrossRef] [PubMed]

12. Tam, K.I.; Roner, M.R. Characterization of in vivo anti-rotavirus activities of saponin extracts from Quillaja saponaria Molina. Antiviral Res. 2011, 90, 231-241. [CrossRef] [PubMed]

13. Roner, M.R.; Tam, K.I.; Barrager, M.K. Prevention of rotavirus infections in vitro with aqueous extracts of Quillaja saponaria Molina. Futur. Med Chem 2010, 14, 384-399. [CrossRef]

14. Dixit, V.; Tewari, J.; Obendorf, S.K. Fungal Growth Inhibition of Regenerated Cellulose Nanofibrous Membranes Containing Quillaja Saponin. Arch. Environ. Con. Tox. 2010, 59, 417-423. [CrossRef] [PubMed]

15. Holtshausen, L.; Chaves, A.V.; Beauchemin, K.A.; McGinn, S.M.; McAllister, T.A.; Odongo, N.E.; Cheeke, P.R.; Benchaar, C. Feeding saponin-containing Yucca schidigera and Quillaja saponaria to decrease enteric methane production in dairy cows. J. Dairy Sci. 2009, 92, 2809-2821. [CrossRef] [PubMed]

16. Sen, S.; Makkar, H.P.S.; Muetzel, S.; Becker, K. Effect of Quillaja saponaria saponins and Yucca schidigera plant extract on growth of Escherichia coli. Lett. Appl. Microbiol. 1998, 27, 35-38. [CrossRef] [PubMed]

17. Pen, B.; Sar, C.; Mwenya, B.; Kuwaki, K.; Morikawa, R.; Takahashi, J. Effects of Yucca schidigera and Quillaja saponaria extracts on in vitro ruminal fermentation and methane emission. Anim. Feed Sci. Technol. 2006, 129, 175-186. [CrossRef]

18. Rajput, Z.I.; Hu, S.; Xiao, C.; Arijo, A.G. Adjuvant effects of saponins on animal immune responses. J. Zhejiang Univ. Sci. B 2007, 8, 153-161. [CrossRef] [PubMed]

19. Sjölander, A.; Drane, D.; Maraskovsky, E.; Scheerlinck, J.P.; Suhrbier, A.; Tennent, J.; Pearse, M. Immune responses to ISCOM ${ }^{\circledR}$ formulations in animal and primate models. Vaccine 2001, 19, 2661-2665. [CrossRef]

20. Paula Barbosa, A. de Saponins as immunoadjuvant agent: A review. African J. Pharm. Pharmacol. 2014, 8, 1049-1057. [CrossRef]

21. Marty-Roix, R.; Vladimer, G.I.; Pouliot, K.; Weng, D.; Buglione-Corbett, R.; West, K.; MacMicking, J.D.; Chee, J.D.; Wang, S.; Lu, S.; et al. Identification of QS-21 as an Inflammasome-activating Molecular Component of Saponin Adjuvants. J. Biol. Chem. 2016, 291, 1123-1136. [CrossRef] [PubMed]

22. Demana, P.H.; Davies, N.M.; Vosgerau, U.; Rades, T. Pseudo-ternary phase diagrams of aqueous mixtures of Quil A, cholesterol and phospholipid prepared by the lipid-film hydration method. Int. J. Pharm. 2004, 270, 229-239. [CrossRef]

23. Myschik, J.; Lendemans, D.G.; McBurney, W.T.; Demana, P.H.; Hook, S.; Rades, T. On the preparation, microscopic investigation and application of ISCOMs. Micron. 2006, 37, 724-734. [CrossRef] [PubMed]

24. De Groot, C.; Müller-Goymann, C.C. Saponin Interactions with Model Membrane Systems-Langmuir Monolayer Studies, Hemolysis and Formation of ISCOMs. Planta Med. 2016, 82, 1496-1512. [CrossRef] [PubMed]

25. Cibulski, S.P.; Mourglia-Ettlin, G.; Teixeira, T.F.; Quirici, L.; Roehe, P.M.; Ferreira, F.; Silveira, F. Novel ISCOMs from Quillaja brasiliensis saponins induce mucosal and systemic antibody production, T-cell responses and improved antigen uptake. Vaccine 2016, 34, 1162-1171. [CrossRef]

26. De Costa, F.; Yendo, A.C.A.; Cibulski, S.P.; Fleck, J.D.; Roehe, P.M.; Spilki, F.R.; Gosmann, G.; Fett-Neto, A.G. Alternative inactivated poliovirus vaccines adjuvanted with Quillaja brasiliensis or Quil-A saponins are equally effective in inducing specific immune responses. PLoS ONE 2014, 9, e105374. [CrossRef] [PubMed] 
27. Silveira, F.; Cibulski, S.P.; Varela, A.P.; Marqués, J.M.; Chabalgoity, A.; de Costa, F.; Yendo, A.C.A.; Gosmann, G.; Roehe, P.M.; Fernández, C.; Ferreira, F. Quillaja brasiliensis saponins are less toxic than Quil A and have similar properties when used as an adjuvant for a viral antigen preparation. Vaccine 2011, 29, 9177-9182. [CrossRef] [PubMed]

28. Fleck, J.D.; Kauffmann, C.; Spilki, F.; Lencina, C.L.; Roehe, P.M.; Gosmann, G. Adjuvant activity of Quillaja brasiliensis saponins on the immune responses to bovine herpesvirus type 1 in mice. Vaccine 2006, 24, 7129-7134. [CrossRef]

29. Wallace, F.; Bennadji, Z.; Ferreira, F.; Olivaro, C. Analysis of an immunoadjuvant saponin fraction from Quillaja brasiliensis leaves by electrospray ionization ion trap multiple-stage mass spectrometry. Phytochem. Lett. 2017, 20, 228-233. [CrossRef]

30. Kite, G.C.; Howes, M.J.R.; Simmonds, M.S.J. Metabolomic analysis of saponins in crude extracts of Quillaja saponaria by liquid chromatography/mass spectrometry for product authentication. Rapid Commun. Mass Spectrom. 2004, 18, 2859-2870. [CrossRef]

31. Jacobsen, N.E.; Fairbrother, W.J.; Kensil, C.R.; Lim, A.; Wheeler, D.A.; Powell, M.F. Structure of the saponin adjuvant QS-21 and its base-catalyzed isomerization product by $1 \mathrm{H}$ and natural abundance ${ }^{13} \mathrm{C}-\mathrm{NMR}$ spectroscopy. Carbohydr. Res. 1996, 280, 1-14. [CrossRef]

32. Kauffmann, C.; Machado, A.M.; Fleck, J.D.; Provensi, G.; Pires, V.S.; Guillaume, D.; Sonnet, P.; Reginatto, F.H.; Schenkel, E.P.; Gosmann, G. Constituents from leaves of Quillaja brasiliensis. Nat. Prod. Res. 2004, 18, $153-157$. [CrossRef]

33. Guo, S.; Lennart, K.; Lundgren, L.N.; Rönnberg, B.; Sundquist, B.G. Triterpenoid saponins from Quillaja saponaria. Phytochemistry 1998, 48, 175-180. [CrossRef]

34. Guo, S.; Kenne, L. Structural studies of triterpenoid saponins with new acyl components from Quillaja saponaria Molina. Phytochemistry 2000, 55, 419-428. [CrossRef]

35. Guo, S.; Kenne, L. Characterization of some O-acetylated saponins from Quillaja saponaria Molina. Phytochemistry 2000, 54, 615-623. [CrossRef]

36. Nyberg, N.T.; Kenne, L.; Rönnberg, B.; Sundquist, B.G. Separation and structural analysis of some saponins from Quillaja saponaria Molina. Carbohydr. Res. 1999, 323, 87-97. [CrossRef]

37. Nyberg, N.T.; Baumann, H.; Kenne, L. Solid-phase extraction NMR studies of chromatographic fractions of saponins from Quillaja saponaria. Anal. Chem. 2003, 75, 268-274. [CrossRef] [PubMed]

38. Hassan, S.M.; Byrd, J.A.; Cartwright, A.L.; Bailey, C.A. Hemolytic and Antimicrobial Activities Differ Among Saponin-rich Extracts From Guar, Quillaja, Yucca, and Soybean. Appl. Biochem. Biotechnol. 2010, 162, 1008-1017. [CrossRef] [PubMed]

39. Makkar, H.P.S.; Sen, S.; Blümmel, M.; Becker, K. Effects of fractions containing saponins from Yucca schidigera, Quillaja saponaria, and Acacia auriculoformis on rumen fermentation. J. Agric. Food Chem. 1998, 46, 4324-4328. [CrossRef]

40. Wallace, R.J.; Arthaud, L.; Newbold, C.J. Influence of Yucca shidigera extract on ruminal ammonia concentrations and ruminal microorganisms. Appl. Environ. Microbiol. 1994, 60, 1762-1767.

41. Bangham, A.D.; Horne, R.W. Action of saponin on biological cell membranes. Nature 1962, 196, $952-955$. [CrossRef]

42. Oda, K.; Matsuda, H.; Murakami, T.; Katayama, S.; Ohgitani, T.; Yoshikawa, M. Adjuvant and haemolytic activities of 47 saponins derived from medicinal and food plants. Biol. Chem. 2000, 381, 67-74. [CrossRef]

43. Baumann, E.; Stoya, G.; Vo, A.; Richter, W.; Lemke, C.; Linss, W. Hemolysis of human erythrocytes with saponin affects the membrane structure. Acta Histochem. 2000, 35. [CrossRef] [PubMed]

44. Walther, R.U.; Padilla, L.; González, J.; Otero, R. Quillaja saponaria wood extract Refined processing and forestry management guarantee sustainability and ecological benefits. Compend. Deterg. 2011, 2, 3-4.

45. Bachran, C.; Sutherland, M.; Heisler, I.; Hebestreit, P.; Melzig, M.F.; Fuchs, H. The saponin-mediated enhanced uptake of targeted saporin-based drugs is strongly dependent on the saponin structure. Exp. Biol. Med. 2006, 231, 412-420. [CrossRef]

46. Arabski, M.; We, A.; Czerwonka, G.; Lankoff, A.; Kaca, W. Effects of Saponins against Clinical E. coli Strains and Eukariotic Cell Line. J. Biomed. Biotechnol. 2012, 1-6. [CrossRef] [PubMed]

47. Sewlikar, S.; D'Souza, D.H. Antimicrobial Effects of Quillaja saponaria Extract Against Escherichia coli O157:H7 and the Emerging Non-O157 Shiga Toxin-Producing E. coli. J. Food Sci. 2017, 82, 1171-1177. [CrossRef] [PubMed] 
48. Antolak, H.; Mizerska, U.; Berlowska, J.; Otlewska, A.; Krȩgiel, D. Quillaja saponaria Saponins with potential to enhance the effectiveness of disinfection processes in the beverage industry. Appl. Sci. 2018, 8, 368. [CrossRef]

49. Yoshiki, Y.; Kudou, S.; Okubo, K. Relationship between Chemical Structures and Biological Activities of Triterpenoid Saponins from Soybean. Biosci. Biotechnol. Biochem 1998, 62, 2291-2299. [CrossRef]

50. Patra, A.K.; Saxena, J. The effect and mode of action of saponins on the microbial populations and fermentation in the rumen and ruminant production. Nutr. Res. Rev. 2009, 22, 204-219. [CrossRef]

51. Bei, L.; Hu, T.; Qian, Z.M.; Shen, X. Extracellular $\mathrm{Ca}^{2+}$ regulates the respiratory burst of human neutrophils. Biochim. Biophys. Acta 1998, 1404, 475-483. [CrossRef]

52. Chapagain, B.P.; Wiesman, Z.; Tsror (Lahkim) L., L. In vitro study of the antifungal activity of saponin-rich extracts against prevalent phytopathogenic fungi. Ind. Crops Prod. 2007, 26, 109-115. [CrossRef]

53. Grabensteiner, E.; Arshad, N.; Hess, M. Differences in the in vitro susceptibility of mono-eukaryotic cultures of Histomonas meleagridis, Tetratrichomonas gallinarum and Blastocystis sp. to natural organic compounds. Parasitol. Res. 2007, 101, 193-199. [CrossRef] [PubMed]

54. Rocha, T.D.; De Brum Vieira, P.; Gnoatto, S.C.B.; Tasca, T.; Gosmann, G. Anti-Trichomonas vaginalis activity of saponins from Quillaja, Passiflora, and Ilex species. Parasitol. Res. 2012, 110, 2551-2556. [CrossRef] [PubMed]

55. Francis, G.; Kerem, Z.; Makkar, H.P.S.; Becker, K. The biological action of saponins in animal systems: A review. Br. J. Nutr. 2002, 88, 587-605. [CrossRef] [PubMed]

56. Wang, Z.-P. Saponins as Anticancer Agent. United States Pat. Appl. Publ. 2005, 2005/01756, 1-10.

57. Ebbesen, P.; Dalsgaard, K. Prolonged survival of AKR mice treated with the Saponin adjuvant Quil A. Acta Path. Microbiol 1976, 84, 358-360. [CrossRef]

58. Hu, K.; Berenjian, S.; Larsson, R.; Gullbo, J.; Nygren, P.; Lövgren, T.; Morein, B. Nanoparticulate Quillaja saponin induces apoptosis in human leukemia cell lines with a high therapeutic index. Int. J. Nanomedicine 2010, 5, 51-62. [CrossRef] [PubMed]

59. Ahmed Abdel-Reheim, M.; Messiha, B.A.S.; Abo-Saif, A.A. Quillaja saponaria bark saponin protects Wistar rats against ferrous sulphate-induced oxidative and inflammatory liver damage. Pharm. Biol. 2017, 55, 1972-1983. [CrossRef] [PubMed]

60. Lee, K.J.; Choi, J.H.; Kim, H.G.; Han, E.H.; Hwang, Y.P.; Lee, Y.C.; Chung, Y.C.; Jeong, H.G. Protective effect of saponins derived from the roots of Platycodon grandiflorum against carbon tetrachloride induced hepatotoxicity in mice. Food Chem. Toxicol. 2008, 46, 1778-1785. [CrossRef] [PubMed]

61. Yu, H.; Zheng, L.; Yin, L.; Xu, L.; Qi, Y.; Han, X.; Xu, Y.; Liu, K.; Peng, J. Protective effects of the total saponins from Dioscorea nipponica Makino against carbon tetrachloride-induced liver injury in mice through suppression of apoptosis and inflammation. Int. Immunopharmacol. 2014, 19, 233-244. [CrossRef] [PubMed]

62. Rao, D.; Gurfinkel, D. The bioactivity of saponins: Triterpenoid and steroidal glycosides. Drug Metab. Drug Interact 2000, 17, 211-236.

63. Bomford, R.; Stapleton, M.; Winsor, S.; Beesley, J.E.; Jessup, E.A.; Price, K.R.; Fenwick, G.R. Adjuvanticity and ISCOM formation by structurally diverse saponins. Vaccine 1992, 10, 572-577. [CrossRef]

64. van Setten, D.C.; van de Werken, G. Molecular Structures of Saponins from Quillaja saponaria Molina. In Saponins Used in Traditional and Modern Medicine; Waller, G.R., Yamasaki, K., Eds.; Springer: Boston, MA, USA, 1996; pp. 185-193. ISBN 978-1-4899-1367-8.

65. Ríos, J.-L. Effects of triterpenes on the immune system. J. Ethnopharmacol. 2010, 128, 1-14. [CrossRef] [PubMed]

66. Guo, H.; Callaway, J.B.; Ting, J.P.-Y. Inflammasomes: Mechanism of action, role in disease, and therapeutics. Nat. Med. 2015, 21, 677-687. [CrossRef] [PubMed]

67. Coffman, R.L.; Sher, A.; Seder, R.A. Vaccine Adjuvants: Putting Innate Immunity to Work. Immunity 2010, 33, 492-503. [CrossRef]

68. Ahlberg, V.; Hjertner, B.; Wallgren, P.; Hellman, S.; Lövgren Bengtsson, K.; Fossum, C. Innate immune responses induced by the saponin adjuvant Matrix-M in specific pathogen free pigs. Vet. Res. 2017, 48, 30. [CrossRef] [PubMed]

69. Podolak, I.; Galanty, A.; Sobolewska, D. Saponins as cytotoxic agents: A review. Phytochem. Rev. 2010, 9, 425-474. [CrossRef] [PubMed] 
70. Fernando, G.J.P.; Stewart, T.J.; Tindle, R.W.; Frazer, I.H. Vaccine-induced Th1-type responses are dominant over Th2-type responses in the short term whereas pre-existing Th2 responses are dominant in the longer term. Scand. J. Immunol. 1998, 47, 459-465. [CrossRef]

71. Katayama, S.; Mine, Y. Quillaja saponin can modulate ovalbumin-induced IgE allergic responses through regulation of Th1/Th2 balance in a murine model. J. Agric. Food Chem. 2006, 54, 3271-3276. [CrossRef]

72. Newman, M.J.; Wu, J.Y.; Gardner, B.H.; Anderson, C.A.; Kensil, C.R.; Recchia, J.; Coughlin, R.T.; Powell, M.F. Induction of cross-reactive cytotoxic T-lymphocyte responses specific for HIV-1 gp120 using saponin adjuvant (QS-21) supplemented subunit vaccine formulations. Vaccine 1997, 15, 1001-1007. [CrossRef]

73. Marciani, D.J. Elucidating the Mechanisms of Action of Saponin-Derived Adjuvants. Trends Pharmacol. Sci. 2018, 39, 573-585. [CrossRef]

74. Stills, H.F. Adjuvants and Antibody Production: Dispelling the Myths Associated with Freund's Complete and Other Adjuvants. ILAR J. 2005, 46, 280-293. [CrossRef] [PubMed]

75. Awate, S.; Babiuk, L.A.; Mutwiri, G. Mechanisms of action of adjuvants. Front. Immunol. 2013, 4, 1-10. [CrossRef] [PubMed]

76. Barr, I.G.; Sjölander, A.; Cox, J.C. ISCOMs and other saponin based adjuvants. Adv. Drug Deliv. Rev. 1998, 32, 247-271. [CrossRef]

77. Garcia, A.; Lema, D. An Updated Review of ISCOMSTM and ISCOMATRIXTM Vaccines. Curr. Pharm. Des. 2016, 22, 6294-6299. [CrossRef]

78. Sjölander, A.; Cox, J.C.; Barr, I.G. ISCOMs: An adjuvant with multiple functions. J. Leukoc. Biol. 1998, 64, 713-723. [CrossRef]

79. Karandikar, S.; Mirani, A.; Waybhase, V.; Patravale, V.B.; Patankar, S. Nanovaccines for Oral Delivery-Formulation Strategies and Challenges; Elsevier Inc.: London, UK, 2017; ISBN 9780323477208.

80. Garçon, N.; Chomez, P.; Van Mechelen, M. GlaxoSmithKline Adjuvant Systems in vaccines: Concepts, achievements and perspectives. Expert Rev. Vaccines 2007, 6, 723-739. [CrossRef]

81. Garg, R.; Babiuk, L.; van Drunen Littel-van den Hurk, S.; Gerdts, V. A novel combination adjuvant platform for human and animal vaccines. Vaccine 2017, 35, 4486-4489. [CrossRef]

82. Lacaille-Dubois, M.A.; Wagner, H. A review of the biological and pharmacological activities of saponins. Phytomedicine 1996, 2, 363-386. [CrossRef]

83. Slovin, S.F.; Ragupathi, G.; Fernandez, C.; Jefferson, M.P.; Diani, M.; Wilton, A.S.; Powell, S.; Spassova, M.; Reis, C.; Clausen, H.; et al. A bivalent conjugate vaccine in the treatment of biochemically relapsed prostate cancer: A study of glycosylated MUC-2-KLH and Globo H-KLH conjugate vaccines given with the new semi-synthetic saponin immunological adjuvant GPI-0100 OR QS-21. Vaccine 2005, 23, 3114-3122. [CrossRef]

84. Jansen, C.; Kuipers, B.; Van Der Biezen, J.; De Cock, H.; Van Der Ley, P.; Tommassen, J. Immunogenicity of in vitro folded outer membrane protein PorA of Neisseria meningitidis. FEMS Immunol. Med. Microbiol. 2000, 27, 227-233. [CrossRef]

85. Shu, Q.; Bird, S.H.; Gill, H.S.; Duan, E.; Xu, Y.; Hillard, M.A.; Rowe, J.B.; Industry, B.; Health, H.; North, P.; et al. Antibody Response in Sheep Following Immunization with Streptococcus bovis in Different Adjuvants. Vet. Res. Commun. 2001, 25, 43-54. [CrossRef] [PubMed]

86. Da Fonseca, D.P.A.J.; Frerichs, J.; Singh, M.; Snippe, H.; Verheul, A.F.M. Induction of antibody and T-cell responses by immunization with ISCOMS containing the 38-kilodalton protein of Mycobacterium tuberculosis. Vaccine 2000, 19, 122-131. [CrossRef]

87. Boyaka, P.N.; Marinaro, M.; Jackson, R.J.; van Ginkel, F.W.; Cormet-Boyaka, E.; Kirk, K.L.; Kensil, C.R.; McGhee, J.R. Oral QS-21 requires early IL-4 help for induction of mucosal and systemic immunity. J. Immunol. 2001, 166, 2283-2290. [CrossRef] [PubMed]

88. Kumar, S.; Malhotra, D.V.; Dhar, S.; Nichani, A.K. Vaccination of donkeys against Babesia equi using killed merozoite immunogen. Vet. Parasitol. 2002, 106, 19-33. [CrossRef]

89. Liu, G.; Anderson, C.; Scaltreto, H.; Barbon, J.; Kensil, C.R. QS-21 structure/function studies: Effect of acylation on adjuvant activity. Vaccine 2002, 20, 2808-2815. [CrossRef]

90. Borja-Cabrera, G.P.; Correia Pontes, N.N.; Da Silva, V.O.; Paraguai De Souza, E.; Santos, W.R.; Gomes, E.M.; Luz, K.G.; Palatnik, M.; Palatnik De Sousa, C.B. Long lasting protection against canine kala-azar using the FML-QuilA saponin vaccine in an endemic area of Brazil (São Gonçalo do Amarante, RN). Vaccine 2002, 20, 3277-3284. [CrossRef] 
91. Stittelaar, K.J.; Vos, H.W.; Van Amerongen, G.; Kersten, G.F.A.; Osterhaus, A.D.M.E.; De Swart, R.L. Longevity of neutralizing antibody levels in macaques vaccinated with Quil A-adjuvanted measles vaccine candidates. Vaccine 2002, 21, 155-157. [CrossRef]

92. Marciani, D.J.; Ptak, R.G.; Voss, T.G.; Reynolds, R.C.; Pathak, A.K.; Chamblin, T.L.; Scholl, D.R.; May, R.D. Corrigendum to "Degradation of Quillaja saponaria Molina saponins: Loss of the protective effects of a herpes simplex virus 1 subunit vaccine" [International Immunopharmacology 2/12 (2002) 1703-1711]. Int. Immunopharmacol. 2005, 5, 1658. [CrossRef]

93. De Jonge, M.I.; Vidarsson, G.; Van Dijken, H.H.; Hoogerhout, P.; Van Alphen, L.; Dankert, J.; Van der Ley, P. Functional activity of antibodies against the recombinant OpaJ protein from Neisseria meningitidis. Infect. Immun. 2003, 71, 2331-2340. [CrossRef]

94. Zhang, P.; Yang, Q.B.; Marciani, D.J.; Martin, M.; Clements, J.D.; Michalek, S.M.; Katz, J. Effectiveness of the quillaja saponin semi-synthetic analog GPI-0100 in potentiating mucosal and systemic responses to recombinant HagB from Porphyromonas gingivalis. Vaccine 2003, 21, 4459-4471. [CrossRef]

95. Borja-Cabrera, G.P.; Mendes, A.C.; Paraguai De Souza, E.; Okada, L.Y.H.; Trivellato, F.A.D.A.; Kawasaki, J.K.A.; Costa, A.C.; Reis, A.B.; Genaro, O.; Batista, L.M.M.; et al. Effective immunotherapy against canine visceral leishmaniasis with the FML-vaccine. Vaccine 2004, 22, 2234-2243. [CrossRef] [PubMed]

96. Regner, M.; Culley, F.; Fontannaz, P.; Hu, K.; Morein, B.; Lambert, P.H.; Openshaw, P.; Siegrist, C.A. Safety and efficacy of immune-stimulating complex-based antigen delivery systems for neonatal immunisation against respiratory syncytial virus infection. Microbes Infect. 2004, 6, 666-675. [CrossRef] [PubMed]

97. Palatnik De Sousa, C.B.; Santos, W.R.; Casas, C.P.; Paraguai De Souza, E.; Tinoco, L.W.; Da Silva, B.P.; Palatnik, M.; Parente, J.P. Protective vaccination against murine visceral leishmaniasis using aldehyde-containing Quillaja saponaria sapogenins. Vaccine 2004, 22, 2470-2479. [CrossRef] [PubMed]

98. Demana, P.H.; Fehske, C.; White, K.; Rades, T.; Hook, S. Effect of incorporation of the adjuvant Quil A on structure and immune stimulatory capacity of liposomes. Immunol. Cell Biol. 2004, 82, 547-554. [CrossRef] [PubMed]

99. Skeiky, Y.A.W.; Alderson, M.R.; Ovendale, P.J.; Guderian, J.A.; Brandt, L.; Dillon, D.C.; Campos-Neto, A.; Lobet, Y.; Dalemans, W.; Orme, I.M.; et al. Differential Immune Responses and Protective Efficacy Induced by Components of a Tuberculosis Polyprotein Vaccine, Mtb72F, Delivered as Naked DNA or Recombinant Protein. J. Immunol. 2004, 172, 7618-7628. [CrossRef] [PubMed]

100. Meraldi, V.; Romero, J.F.; Kensil, C.; Corradin, G. A strong CD8+T cell response is elicited using the synthetic polypeptide from the C-terminus of the circumsporozoite protein of Plasmodium berghei together with the adjuvant QS-21: Quantitative and phenotypic comparison with the vaccine model of irradiate. Vaccine 2005, 23, 2801-2812. [CrossRef] [PubMed]

101. Hu, K.F.; Regner, M.; Siegrist, C.A.; Lambert, P.; Chen, M.; Bengtsson, K.L.; Morein, B. The immunomodulating properties of human respiratory syncytial virus and immunostimulating complexes containing Quillaja saponin components QH-A, QH-C and ISCOPREPTM703. FEMS Immunol. Med. Microbiol. 2005, 43, 269-276. [CrossRef] [PubMed]

102. Cristillo, A.D.; Wang, S.; Caskey, M.S.; Unangst, T.; Hocker, L.; He, L.; Hudacik, L.; Whitney, S.; Keen, T.; Chou, T.H.W.; et al. Preclinical evaluation of cellular immune responses elicited by a polyvalent DNA prime/protein boost HIV-1 vaccine. Virology 2006, 346, 151-168. [CrossRef]

103. Oliveira-Freitas, E.; Casas, C.P.; Borja-Cabrera, G.P.; Santos, F.N.; Nico, D.; Souza, L.O.P.; Tinoco, L.W.; da Silva, B.P.; Palatnik, M.; Parente, J.P.; et al. Acylated and deacylated saponins of Quillaja saponaria mixture as adjuvants for the FML-vaccine against visceral leishmaniasis. Vaccine 2006, 24, 3909-3920. [CrossRef]

104. Pickering, R.J.; Smith, S.D.; Strugnell, R.A.; Wesselingh, S.L.; Webster, D.E. Crude saponins improve the immune response to an oral plant-made measles vaccine. Vaccine 2006, 24, 144-150. [CrossRef]

105. López-Abán, J.; Casanueva, P.; Nogal, J.; Arias, M.; Morrondo, P.; Diez-Baños, P.; Hillyer, G.V.; Martínez-Fernández, A.R.; Muro, A. Progress in the development of Fasciola hepatica vaccine using recombinant fatty acid binding protein with the adjuvant adaptation system ADAD. Vet. Parasitol. 2007, 145, 287-296. [CrossRef] [PubMed]

106. Parra, L.E.; Borja-Cabrera, G.P.; Santos, F.N.; Souza, L.O.P.; Palatnik-de-Sousa, C.B.; Menz, I. Safety trial using the Leishmune ${ }^{\circledR v}$ accine against canine visceral leishmaniasis in Brazil. Vaccine 2007, 25, 2180-2186. [CrossRef] [PubMed] 
107. Quenelle, D.C.; Collins, D.J.; Marciani, D.J.; Kern, E.R. Effect of immunization with herpes simplex virus type-1 (HSV-1) glycoprotein D (gD) plus the immune enhancer GPI-0100 on infection with HSV-1 or HSV-2. Vaccine 2006, 24, 1515-1522. [CrossRef]

108. Deng, K.; Adams, M.M.; Damani, P.; Livingston, P.O.; Ragupathi, G.; Gin, D.Y. Synthesis of QS-21-xylose: Establishment of the immunopotentiating activity of synthetic QS-21 adjuvant with a melanoma vaccine. Angew. Chemie Int. Ed. 2008, 47, 6395-6398. [CrossRef] [PubMed]

109. Kaba, S.A.; Price, A.; Zhou, Z.; Sundaram, V.; Schnake, P.; Goldman, I.F.; Lal, A.A.; Udhayakumar, V.; Todd, C.W. Immune responses of mice with different genetic backgrounds to improved multiepitope, multitarget malaria vaccine candidate antigen FALVAC-1A. Clin. Vaccine Immunol. 2008, 15, 1674-1683. [CrossRef] [PubMed]

110. Borja-Cabrera, G.P.; Santos, F.N.; Bauer, F.S.; Parra, L.E.; Menz, I.; Morgado, A.A.; Soares, I.S.; Batista, L.M.M.; Palatnik-de-Sousa, C.B. Immunogenicity assay of the Leishmune ${ }^{\circledR v a c c i n e ~ a g a i n s t ~ c a n i n e ~}$ visceral leishmaniasis in Brazil. Vaccine 2008, 26, 4991-4997. [CrossRef] [PubMed]

111. Quenelle, D.C.; Collins, D.J.; Rice, T.L.; Prichard, M.N.; Marciani, D.J.; Kern, E.R. Effect of an immune enhancer, GPI-0100, on vaccination with live attenuated herpes simplex virus (HSV) type 2 or glycoprotein D on genital HSV-2 infections of guinea pigs. Antiviral Res. 2008, 80, 223-224. [CrossRef]

112. Radošević, K.; Rodriguez, A.; Mintardjo, R.; Tax, D.; Bengtsson, K.L.; Thompson, C.; Zambon, M.; Weverling, G.J.; UytdeHaag, F.; Goudsmit, J. Antibody and T-cell responses to a virosomal adjuvanted H9N2 avian influenza vaccine: Impact of distinct additional adjuvants. Vaccine 2008, 26, 3640-3646. [CrossRef]

113. Skene, C.D.; Doidge, C.; Sutton, P. Evaluation of ISCOMATRIX ${ }^{\mathrm{TM}}$ and ISCOM $^{\mathrm{TM}}$ vaccines for immunisation against Helicobacter pylori. Vaccine 2008, 26, 3880-3884. [CrossRef]

114. Karanam, B.; Gambhira, R.; Peng, S.; Jagu, S.; Kim, D.-J.; Ketner, G.W.; Stern, P.L.; Adams, R.J.; Roden, R.B.S. Vaccination with HPV16 L2E6E7 fusion protein in GPI-0100 adjuvant elicits protective humoral and cell-mediated immunity. Vaccine 2009, 27, 1040-1049. [CrossRef]

115. Buendía, A.J.; Ortega, N.; Caro, M.R.; Del Río, L.; Gallego, M.C.; Sánchez, J.; Navarro, J.A.; Cuello, F.; Salinas, J. $B$ cells are essential for moderating the inflammatory response and controlling bacterial multiplication in a mouse model of vaccination against Chlamydophila abortus infection. Infect. Immun. 2009, 77, 4868-4876. [CrossRef] [PubMed]

116. Ragupathi, G.; Damani, P.; Srivastava, G.; Srivastava, O.; Sucheck, S.J.; Ichikawa, Y.; Livingston, P.O. Synthesis of sialyl Lewisa (sLea, CA19-9) and construction of an immunogenic sLea vaccine. Cancer Immunol. Immunother. 2009, 58, 1397-1405. [CrossRef] [PubMed]

117. Tafaghodi, M.; Rastegar, S. Preparation and in vivo study of dry powder microspheres for nasal immunization. J. Drug Target. 2010, 18, 235-242. [CrossRef] [PubMed]

118. Duewell, P.; Kisser, U.; Heckelsmiller, K.; Hoves, S.; Stoitzner, P.; Koernig, S.; Morelli, A.B.; Clausen, B.E.; Dauer, M.; Eigler, A.; et al. ISCOMATRIX Adjuvant Combines Immune Activation with Antigen Delivery to Dendritic Cells In Vivo Leading to Effective Cross-Priming of CD8+ T Cells. J. Immunol. 2011, 187, 55-63. [CrossRef] [PubMed]

119. Mohaghegh, M.; Tafaghodi, M. Dextran microspheres could enhance immune responses against PLGA nanospheres encapsulated with tetanus toxoid and Quillaja saponins after nasal immunization in rabbit. Pharm. Dev. Technol. 2011, 16, 36-43. [CrossRef]

120. Tafaghodi, M.; Khamesipour, A.; Jaafari, M.R. Immunization against leishmaniasis by PLGA nanospheres encapsulated with autoclaved Leishmania major (ALM) and CpG-ODN. Parasitol. Res. 2011, 108, 1265-1273. [CrossRef]

121. Ahmed, F.K.; Clark, B.E.; Burton, D.R.; Pantophlet, R. An engineered mutant of HIV-1 gp120 formulated with adjuvant Quil A promotes elicitation of antibody responses overlapping the CD4-binding site. Vaccine 2012, 30, 922-930. [CrossRef]

122. Ariaee, F.M.; Tafaghodia, M. Mucosal adjuvant potential of Quillaja saponins and cross-linked dextran microspheres, co-administered with liposomes encapsulated with tetanus toxoid. Iran. J. Pharm. Res. 2012, 11, 723-732.

123. Reimer, J.M.; Karlsson, K.H.; Lövgren-Bengtsson, K.; Magnusson, S.E.; Fuentes, A.; Stertman, L. Matrix-m ${ }^{\mathrm{TM}}$ adjuvant induces local recruitment, activation and maturation of central immune cells in absence of antigen. PLoS ONE 2012, 7, e41451. [CrossRef] 
124. da Cunha, I.A.L.; Zulpo, D.L.; Bogado, A.L.G.; de Barros, L.D.; Taroda, A.; Igarashi, M.; Navarro, I.T.; Garcia, J.L. Humoral and cellular immune responses in pigs immunized intranasally with crude rhoptry proteins of Toxoplasma gondii plus Quil-A. Vet. Parasitol. 2012, 186, 216-221. [CrossRef]

125. Barhate, G.; Gautam, M.; Gairola, S.; Jadhav, S.; Pokharkar, V. Quillaja saponaria extract as mucosal adjuvant with chitosan functionalized gold nanoparticles for mucosal vaccine delivery: Stability and immunoefficiency studies. Int. J. Pharm. 2013, 441, 636-642. [CrossRef]

126. Buglione-Corbett, R.; Pouliot, K.; Marty-Roix, R.; West, K.; Wang, S.; Lien, E.; Lu, S. Serum Cytokine Profiles Associated with Specific Adjuvants Used in a DNA Prime-Protein Boost Vaccination Strategy. PLoS ONE 2013, 8, e74820. [CrossRef] [PubMed]

127. Fernández-Tejada, A.; Chea, E.K.; George, C.; Gardner, J.R.; Livingston, P.O.; Ragupathi, G.; Tan, D.S.; Gin, D.Y. Design, synthesis, and immunologic evaluation of vaccine adjuvant conjugates based on QS-21 and tucaresol. Bioorg. Med. Chem. 2014, 22, 5917-5923. [CrossRef] [PubMed]

128. Didierlaurent, A.M.; Collignon, C.; Bourguignon, P.; Wouters, S.; Fierens, K.; Fochesato, M.; Dendouga, N.; Langlet, C.; Malissen, B.; Lambrecht, B.N.; et al. Enhancement of Adaptive Immunity by the Human Vaccine Adjuvant AS01 Depends on Activated Dendritic Cells. J. Immunol. 2014, 193, 1920-1930. [CrossRef]

129. Selenica, M.L.B.; Davtyan, H.; Housley, S.B.; Blair, L.J.; Gillies, A.; Nordhues, B.A.; Zhang, B.; Liu, J.; Gestwicki, J.E.; Lee, D.C.; et al. Epitope analysis following active immunization with tau proteins reveals immunogens implicated in tau pathogenesis. J. Neuroinflammation 2014, 11, 1-12. [CrossRef]

130. Dye, J.M.; Warfield, K.L.; Wells, J.B.; Unfer, R.C.; Shulenin, S.; Vu, H.; Nichols, D.K.; Aman, M.J.; Bavari, S. Virus-like particle vaccination protects nonhuman primates from lethal aerosol exposure with marburgvirus (VLP vaccination protects macaques against aerosol challenges). Viruses 2016, 8, 94. [CrossRef] [PubMed]

131. Konduru, K.; Shurtleff, A.C.; Bradfute, S.B.; Nakamura, S.; Bavari, S.; Kaplan, G. Ebolavirus Glycoprotein Fc Fusion Protein Protects Guinea Pigs against Lethal Challenge. PLoS ONE 2016, 11, e0162446. [CrossRef] [PubMed]

132. Ng, H.I.; Fernando, G.J.P.; Depelsenaire, A.C.I.; Kendall, M.A.F. Potent response of QS-21 as a vaccine adjuvant in the skin when delivered with the Nanopatch, resulted in adjuvant dose sparing. Sci. Rep. 2016, 6, 29368. [CrossRef] [PubMed]

133. Detienne, S.; Welsby, I.; Collignon, C.; Wouters, S.; Coccia, M.; Delhaye, S.; Van Maele, L.; Thomas, S.; Swertvaegher, M.; Detavernier, A.; et al. Central role of CD169 ${ }^{+}$lymph node resident macrophages in the adjuvanticity of the QS-21 component of AS01. Sci. Rep. 2016, 6, 1-14. [CrossRef]

134. Rivera, F.; Espino, A.M. Adjuvant-enhanced antibody and cellular responses to inclusion bodies expressing FhSAP2 correlates with protection of mice to Fasciola hepatica. Exp. Parasitol. 2016, 160, 31-38. [CrossRef]

135. Cibulski, S.P.; Silveira, F.; Mourglia-Ettlin, G.; Teixeira, T.F.; dos Santos, H.F.; Yendo, A.C.; de Costa, F.; Fett-Neto, A.G.; Gosmann, G.; Roehe, P.M. Quillaja brasiliensis saponins induce robust humoral and cellular responses in a bovine viral diarrhea virus vaccine in mice. Comp. Immunol. Microbiol. Infect. Dis. 2016, 45, 1-8. [CrossRef]

136. Lambracht-Washington, D.; Fu, M.; Frost, P.; Rosenberg, R.N. Evaluation of a DNA A $\beta 42$ vaccine in adult rhesus monkeys (Macaca mulatta): Antibody kinetics and immune profile after intradermal immunization with full-length DNA A $\beta 42$ trimer. Alzheimer's Res. Ther. 2017, 9, 1-14. [CrossRef] [PubMed]

137. Welsby, I.; Detienne, S.; N’Kuli, F.; Thomas, S.; Wouters, S.; Bechtold, V.; De Wit, D.; Gineste, R.; Reinheckel, T.; Elouahabi, A.; et al. Lysosome-dependent activation of human dendritic cells by the vaccine adjuvant QS-21. Front. Immunol. 2017, 7, 1-16. [CrossRef] [PubMed]

138. Genito, C.J.; Beck, Z.; Phares, T.W.; Kalle, F.; Limbach, K.J.; Stefaniak, M.E.; Patterson, N.B.; Bergmann-Leitner, E.S.; Waters, N.C.; Matyas, G.R.; et al. Liposomes containing monophosphoryl lipid A and QS-21 serve as an effective adjuvant for soluble circumsporozoite protein malaria vaccine FMP013. Vaccine 2017, 35, 3865-3874. [CrossRef] [PubMed]

139. Poirier, D.; Renaud, F.; Dewar, V.; Strodiot, L.; Wauters, F.; Janimak, J.; Shimada, T.; Nomura, T.; Kabata, K.; Kuruma, K.; et al. Hepatitis B surface antigen incorporated in dissolvable microneedle array patch is antigenic and thermostable. Biomaterials 2017, 145, 256-265. [CrossRef] [PubMed]

140. Cibulski, S.P.; Rivera-Patron, M.; Mourglia-Ettlin, G.; Casaravilla, C.; Yendo, A.C.A.; Fett-Neto, A.G.; Chabalgoity, J.A.; Moreno, M.; Roehe, P.M.; Silveira, F. Quillaja brasiliensis saponin-based nanoparticulate adjuvants are capable of triggering early immune responses. Sci. Rep. 2018, 8, 13582. [CrossRef]

141. Wenbin Tuo, D.Z. QS-21: A Potent Vaccine Adjuvant. Nat. Prod. Chem. Res. 2015, 03. [CrossRef] 
142. Lacaille-Dubois, M.A.; Wagner, H. New perspectives for natural triterpene glycosides as potential adjuvants. Phytomedicine 2017, 37, 49-57. [CrossRef]

143. Cibulski, S.; Rivera-Patron, M.; Suárez, N.; Pirez, M.; Rossi, S.; Yendo, A.C.; de Costa, F.; Gosmann, G.; Fett-Neto, A.; Roehe, P.M.; Silveira, F. Leaf saponins of Quillaja brasiliensis enhance long-term specific immune responses and promote dose-sparing effect in BVDV experimental vaccines. Vaccine 2018, 36, 55-65. [CrossRef]

144. Naknukool, S.; Horinouchi, I.; Hatta, H. Stimulating Macrophage Activity in Mice and Humans by Oral Administration of Quillaja Saponin. Biosci. Biotechnol. Biochem. 2011, 75, 1889-1893. [CrossRef]

145. Gilewski, T.; Ragupathi, G.; Bhuta, S.; Williams, L.J.; Musselli, C.; Zhang, X.-F.; Bencsath, K.P.; Panageas, K.S.; Chin, J.; Hudis, C.A.; et al. Immunization of metastatic breast cancer patients with a fully synthetic globo $\mathrm{H}$ conjugate: A phase I trial. Proc. Natl. Acad. Sci. 2001, 98, 3270-3275. [CrossRef] [PubMed]

146. Krug, L.M.; Ragupathi, G.; Ng, K.K.; Hood, C.; Jennings, H.J.; Guo, Z.; Kris, M.G.; Miller, V.; Pizzo, B.; Tyson, L.; et al. Vaccination of Small Cell Lung Cancer Patients with Polysialic Acid or N-Propionylated Polysialic Acid Conjugated to Keyhole Limpet Hemocyanin. Clin. Cancer Res. 2004, 10, 916-923. [CrossRef] [PubMed]

147. Thera, M.A.; Doumbo, O.K.; Coulibaly, D.; Diallo, D.A.; Sagara, I.; Dicko, A.; Diemert, D.J.; Heppner, D.G.; Stewart, V.A.; Angov, E.; et al. Safety and Allele-Specific Immunogenicity of a Malaria Vaccine in Malian Adults: Results of a Phase I Randomized Trial. PLoS Clin. Trials 2006, 1, e34. [CrossRef] [PubMed]

148. Mbawuike, I.; Zang, Y.; Couch, R.B. Humoral and cell-mediated immune responses of humans to inactivated influenza vaccine with or without QS21 adjuvant. Vaccine 2007, 25, 3263-3269. [CrossRef] [PubMed]

149. Evans, T.G.; McElrath, M.J.; Matthews, T.; Montefiori, D.; Weinhold, K.; Wolff, M.; Keefer, M.C.; Kallas, E.G.; Corey, L.; Gorse, G.J.; et al. QS-21 promotes an adjuvant effect allowing for reduced antigen dose during HIV-1 envelope subunit immmunization in humans. Vaccine 2001, 19, 2080-2091. [CrossRef]

150. Leroux-Roels, G.; Van Belle, P.; Vandepapeliere, P.; Horsmans, Y.; Janssens, M.; Carletti, I.; Garçon, N.; Wettendorff, M.; Van Mechelen, M. Vaccine Adjuvant Systems containing monophosphoryl lipid A and QS-21 induce strong humoral and cellular immune responses against hepatitis B surface antigen which persist for at least 4 years after vaccination. Vaccine 2015, 33, 1084-1091. [CrossRef] [PubMed]

151. Krug, L.M.; Ragupathi, G.; Hood, C.; George, C.; Hong, F.; Shen, R.; Abrey, L.; Jennings, H.J.; Kris, M.G.; Livingston, P.O. Immunization with N-propionyl polysialic acid-KLH conjugate in patients with small cell lung cancer is safe and induces IgM antibodies reactive with SCLC cells and bactericidal against group B meningococci. Cancer Immunol. Immunother. 2012, 61, 9-18. [CrossRef]

152. Kruit, W.H.J.; Suciu, S.; Dreno, B.; Mortier, L.; Robert, C.; Chiarion-Sileni, V.; Maio, M.; Testori, A.; Dorval, T.; Grob, J.J.; et al. Selection of immunostimulant AS15 for active immunization with MAGE-A3 protein: Results of a randomized phase II study of the European organisation for research and treatment of cancer melanoma group in metastatic melanoma. J. Clin. Oncol. 2013, 31, 2413-2420. [CrossRef]

153. Vandepapelière, P.; Rehermann, B.; Koutsoukos, M.; Moris, P.; Garçon, N.; Wettendorff, M.; Leroux-Roels, G. Potent enhancement of cellular and humoral immune responses against recombinant hepatitis B antigens using AS02A adjuvant in healthy adults. Vaccine 2005, 23, 2591-2601. [CrossRef]

154. Kester, K.E.; McKinney, D.A.; Tornieporth, N.; Ockenhouse, C.F.; Heppner, D.G.; Hall, T.; Wellde, B.T.; White, K.; Sun, P.; Schwenk, R.; et al. A phase I/IIa safety, immunogenicity, and efficacy bridging randomized study of a two-dose regimen of liquid and lyophilized formulations of the candidate malaria vaccine RTS,S/AS02A in malaria-naïve adults. Vaccine 2007, 25, 5359-5366. [CrossRef]

155. Roestenberg, M.; Remarque, E.; de Jonge, E.; Hermsen, R.; Blythman, H.; Leroy, O.; Imoukhuede, E.; Jepsen, S.; Ofori-Anyinam, O.; Faber, B.; et al. Safety and immunogenicity of a recombinant Plasmodium falciparum AMA1 malaria vaccine adjuvanted with Alhydrogel ${ }^{\mathrm{TM}}$, Montanide ISA 720 or AS02. PLoS ONE 2008, 3, e3960. [CrossRef] [PubMed]

156. Sacarlal, J.; Aponte, J.J.; Aide, P.; Mandomando, I.; Bassat, Q.; Guinovart, C.; Leach, A.; Milman, J.; Macete, E.; Espasa, M.; et al. Safety of the RTS,S/AS02A malaria vaccine in Mozambican children during a Phase IIb trial. Vaccine 2008, 26, 174-184. [CrossRef] [PubMed]

157. Thera, M.A.; Doumbo, O.K.; Coulibaly, D.; Diallo, D.A.; Kone, A.K.; Guindo, A.B.; Traore, K.; Dicko, A.; Sagara, I.; Sissoko, M.S.; et al. Safety and immunogenicity of an AMA-1 malaria vaccine in Malian adults: Results of a phase 1 randomized controlled trial. PLoS ONE 2008, 3, e1465. [CrossRef] [PubMed] 
158. O'Cearbhaill, R.E.; Ragupathi, G.; Zhu, J.; Wan, Q.; Mironov, S.; Yang, G.; Spassova, M.K.; Iasonos, A.; Kravetz, S.; Ouerfelli, O.; et al. A phase i study of unimolecular pentavalent (Globo-H-GM2-sTn-TF-Tn) immunization of patients with epithelial ovarian, fallopian tube, or peritoneal cancer in first remission. Cancers (Basel) 2016, 8, 46. [CrossRef]

159. Coccia, M.; Collignon, C.; Hervé, C.; Chalon, A.; Welsby, I.; Detienne, S.; Van Helden, M.J.; Dutta, S.; Genito, C.J.; Waters, N.C.; et al. Cellular and molecular synergy in AS01-adjuvanted vaccines results in an early IFN $\gamma$ response promoting vaccine immunogenicity. npj Vaccines 2017, 2. [CrossRef] [PubMed]

160. Rönnberg, B.; Fekadu, M.; Morein, B. Adjuvant activity of non-toxic Quillaja saponaria Molina components for use in ISCOM matrix. Vaccine 1995, 13, 1375-1382. [CrossRef]

161. Marciani, D.J.; Pathak, A.K.; Reynolds, R.C.; Seitz, L.; May, R.D. Altered immunomodulating and toxicological properties of degraded Quillaja saponaria Molina saponins. Int. Immunopharmacol. 2001, 1, 813-818. [CrossRef]

162. Rönnberg, B.; Fekadu, M.; Behboudi, S.; Kenne, L.; Morein, B. Effects of carbohydrate modification of Quillaja saponaria Molina QH-B fraction on adjuvant activity, cholesterol-binding capacity and toxicity. Vaccine 1997, 15, 1820-1826. [CrossRef]

163. Abdulla, S.; Oberholzer, R.; Juma, O.; Kubhoja, S.; Machera, F.; Membi, C.; Omari, S.; Urassa, A.; Mshinda, H.; Jumanne, A.; et al. Safety and Immunogenicity of RTS,S/AS02D Malaria Vaccine in Infants. N. Engl. J. Med. 2008, 359, 2533-2544. [CrossRef]

164. Jiang, X.; Cao, Y.; von Gersdorff Jørgensen, L.; Strobel, B.W.; Hansen, H.C.B.; Cedergreen, N. Where does the toxicity come from in saponin extract? Chemosphere 2018, 204, 243-250. [CrossRef]

165. de Koning, C.; Beekhuijzen, M.; Tobor-Kapłon, M.; de Vries-Buitenweg, S.; Schoutsen, D.; Leeijen, N.; van de Waart, B.; Emmen, H. Visualizing Compound Distribution during Zebrafish Embryo Development: The Effects of Lipophilicity and DMSO. Birth Defects Res. Part B Dev. Reprod. Toxicol. 2015, 104, 253-272. [CrossRef] [PubMed]

166. Vinay, T.N.; Park, C.S.; Kim, H.Y.; Jung, S.J. Toxicity and dose determination of quillaja saponin, aluminum hydroxide and squalene in olive flounder (Paralichthys olivaceus). Vet. Immunol. Immunopathol. 2014, 158, 73-85. [CrossRef] [PubMed] 